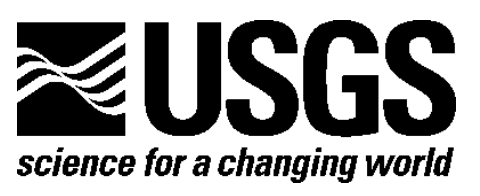

\title{
Mass-Movement Deposits in the Lacustrine Eocene Green River Formation, Piceance Basin, Western Colorado
}

By Ronald C. Johnson, Justin E. Birdwell, Michael E. Brownfield, and Tracey J. Mercier

Open-File Report 2015-1044

U.S. Department of the Interior

U.S. Geological Survey 


\section{U.S. Department of the Interior \\ SALLY JEWELL, Secretary}

\section{U.S. Geological Survey \\ Suzette M. Kimball, Acting Director}

U.S. Geological Survey, Reston, Virginia: 2015

For more information on the USGS—-the Federal source for science about the Earth, its natural and living resources, natural hazards, and the environment-visit http://www.usgs.gov/ or call 1-888-ASK-USGS (1-888-275-8747).

For an overview of USGS information products, including maps, imagery, and publications, visit http://www.usgs.gov/pubprod/.

Any use of trade, firm, or product names is for descriptive purposes only and does not imply endorsement by the U.S. Government.

Although this information product, for the most part, is in the public domain, it also may contain copyrighted materials as noted in the text. Permission to reproduce copyrighted items must be secured from the copyright owner.

Suggested citation:

Johnson, R.C., Birdwell, J.E., Brownfield, M.E., and Mercier, T.J., 2015, Mass-movement deposits in the lacustrine Eocene Green River Formation, Piceance Basin, western Colorado: U.S. Geological Survey Open-File Report 2015-1044, 40 p., http://dx.doi.org/10.3133/ofr20151044.

ISSN 2331-1258 (online) 


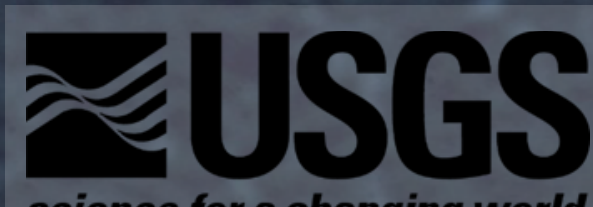

science for a changing world

\section{Mass-Movement Deposits-in the}

Lacustitio Eocene steel iver.

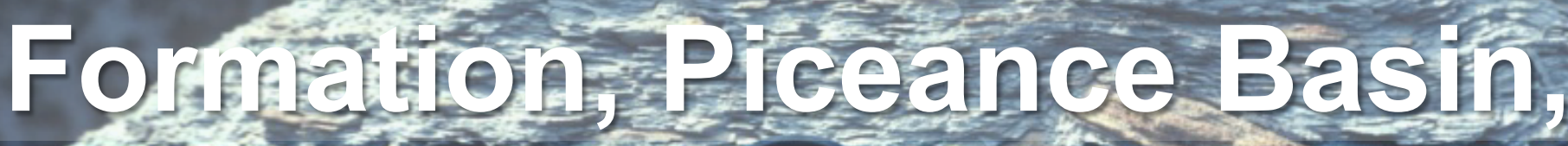

What te Col orado

Ronald C. Johnson, Justin E. Birdwell,

Michael E. Brownfield, and Tracey J. Mercier 


\section{The Eocene Green} River Formation was deposited in two large Eocene saline lakes, Lake Uinta in the Uinta and Piceance Basins and Lake Gosiute in the Greater Green River Basin.

Here we will discuss mass-movement deposits in just the Piceance Basin part of Lake Uinta.

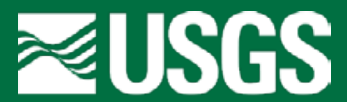

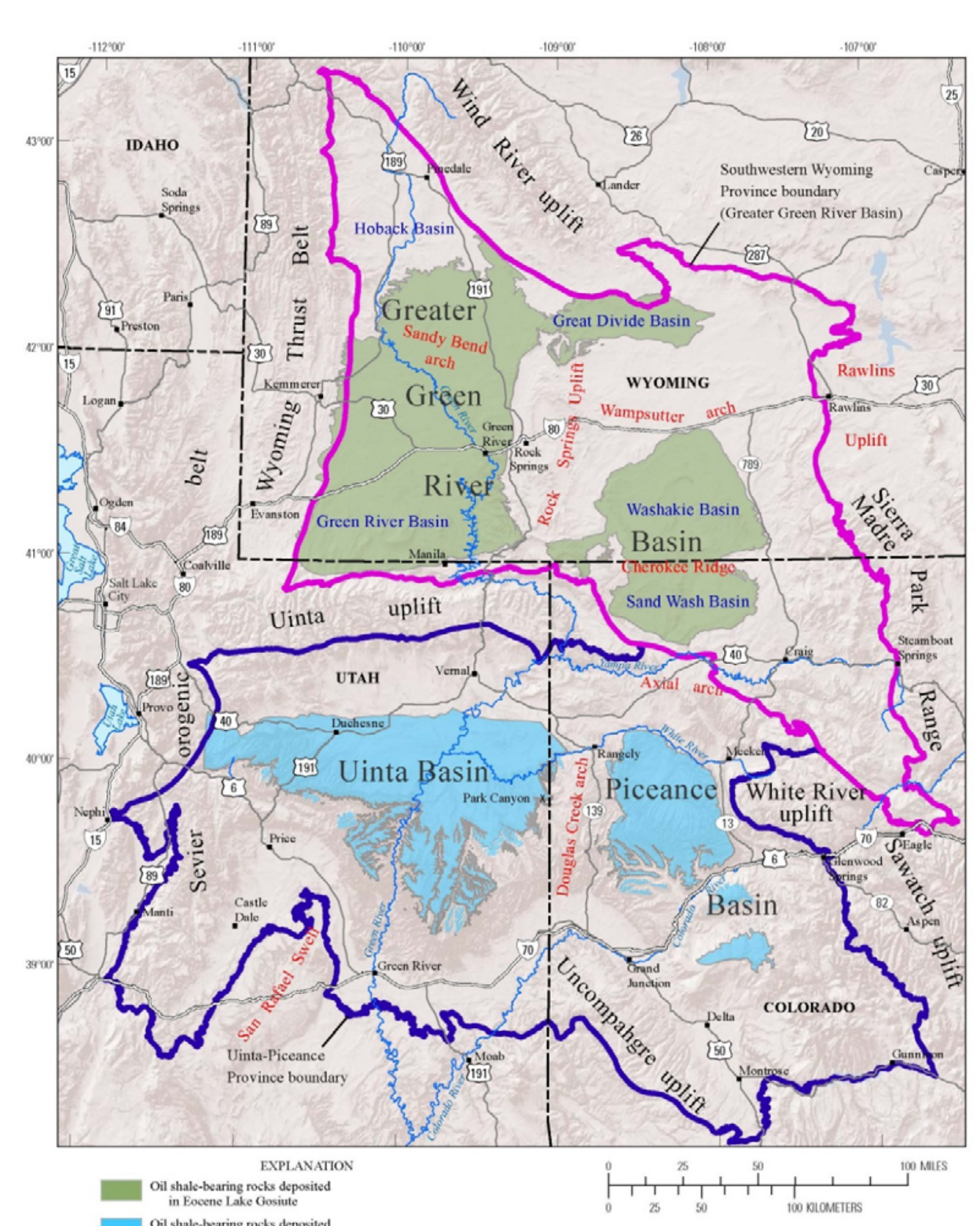

in Eocene Lake Gosiute
Oil shale-bearing rocks deposited in Eocene Lake Uinta us. Geological Survey (2012) 


\section{モUSGS
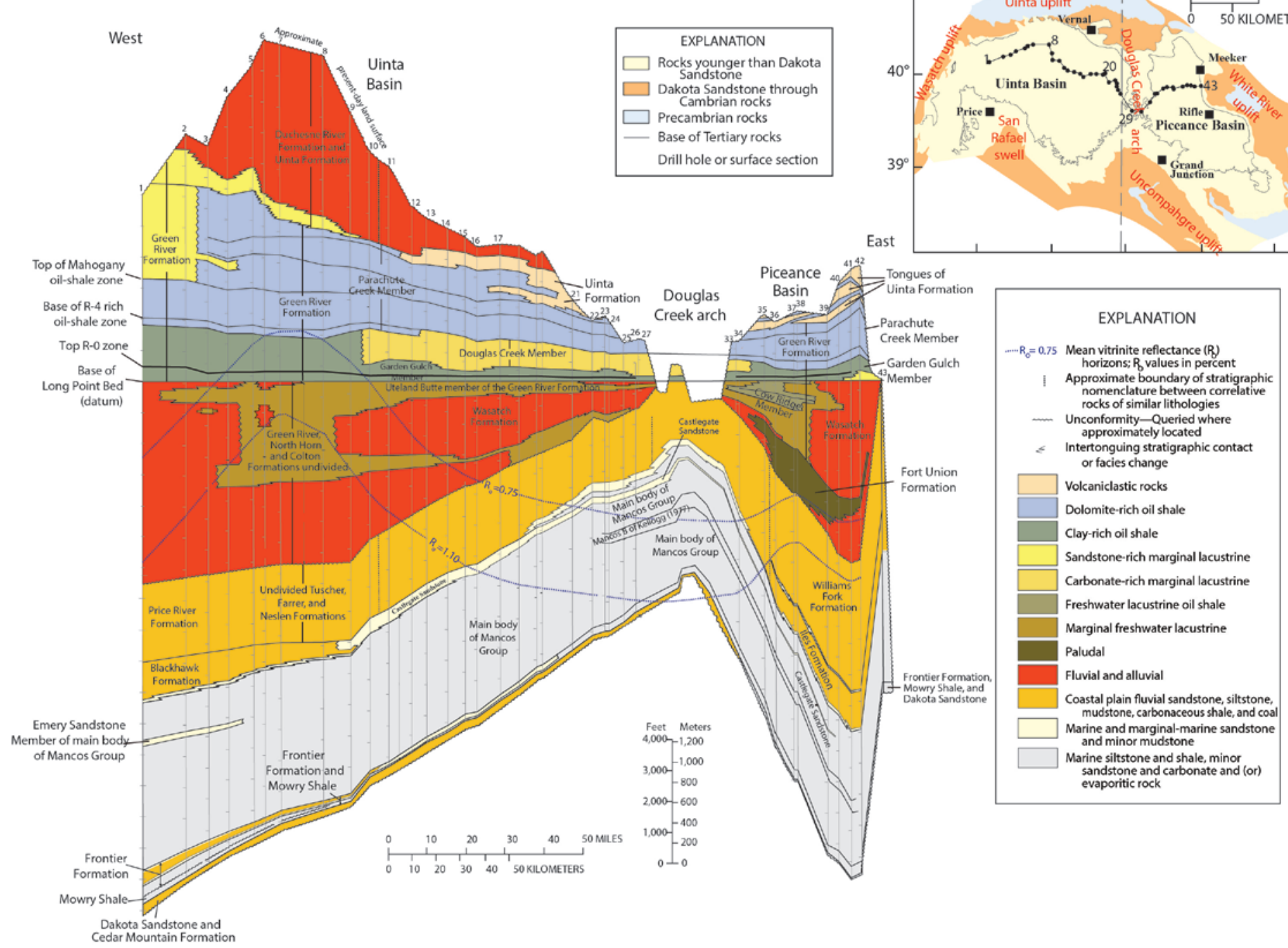

West-east cross section across the Uinta and Piceance Basins and the Douglas Creek arch. The arch acted as a hinge-line between the two subsiding basins. Little sediment was deposited on the crest of the arch prior to the development of saline Lake Uinta. 


\section{In a depositional sense, there are generally two types of oil shale in the Piceance Basin}

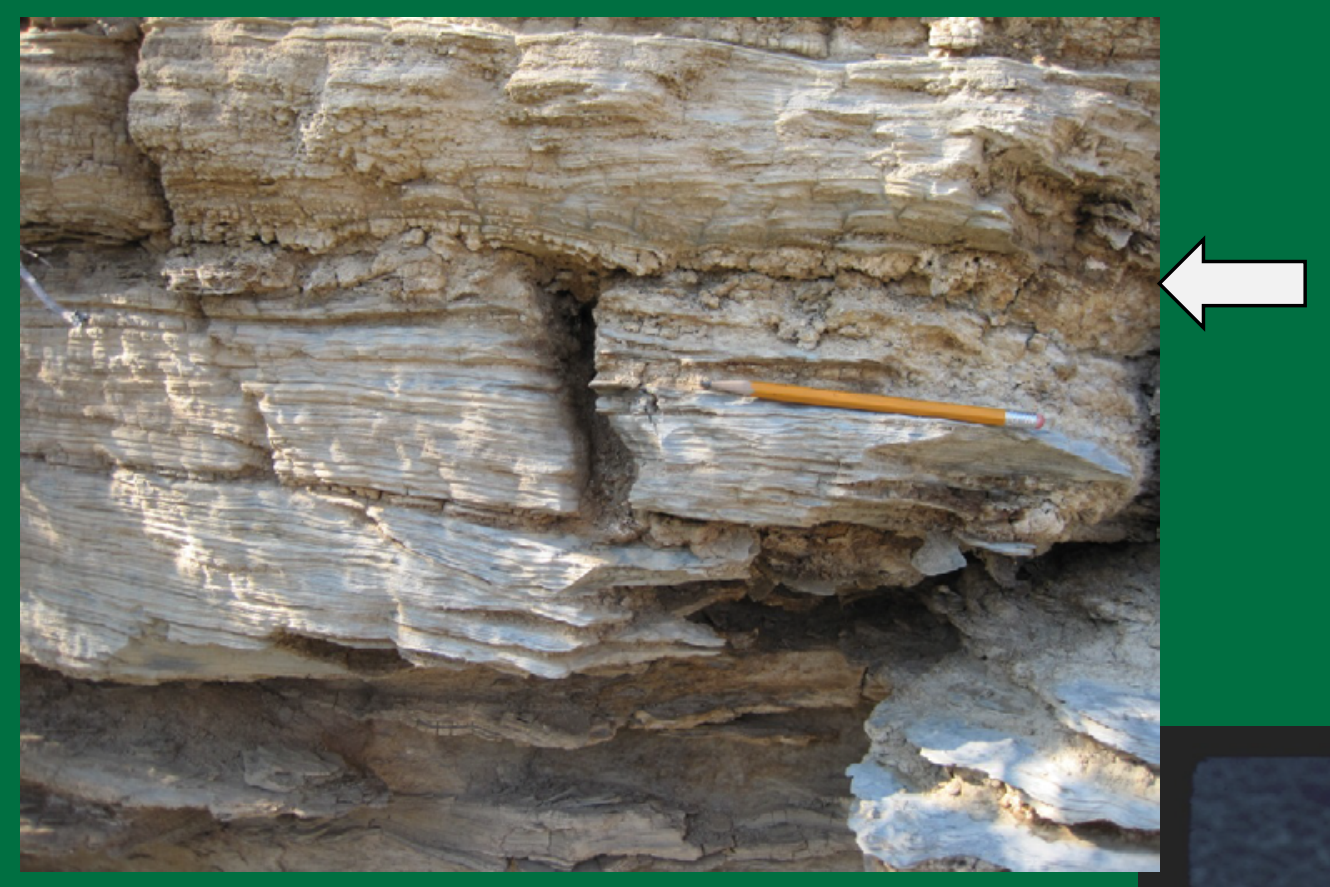

Most people associate the Green River Formation with welllaminated oil shale shown here, largely because it is the dominant type of oil shale where the Green River Formation crops out around the basin margins.

80-112, sec. 16, T. 5 S., R. 98 W., Desert Gulch quadrangle elevation approx. 6,970 feet (ft), elevation top of Mahogany zone about 7,190. Photo is from $220 \mathrm{ft}$ below top Mahogany zone, near middle of R- 6 zone.

But another type of oil shale, generally referred to as "blebby oil shale," appears to have been deposited by mass-movement processes.

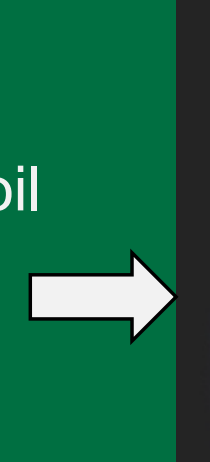




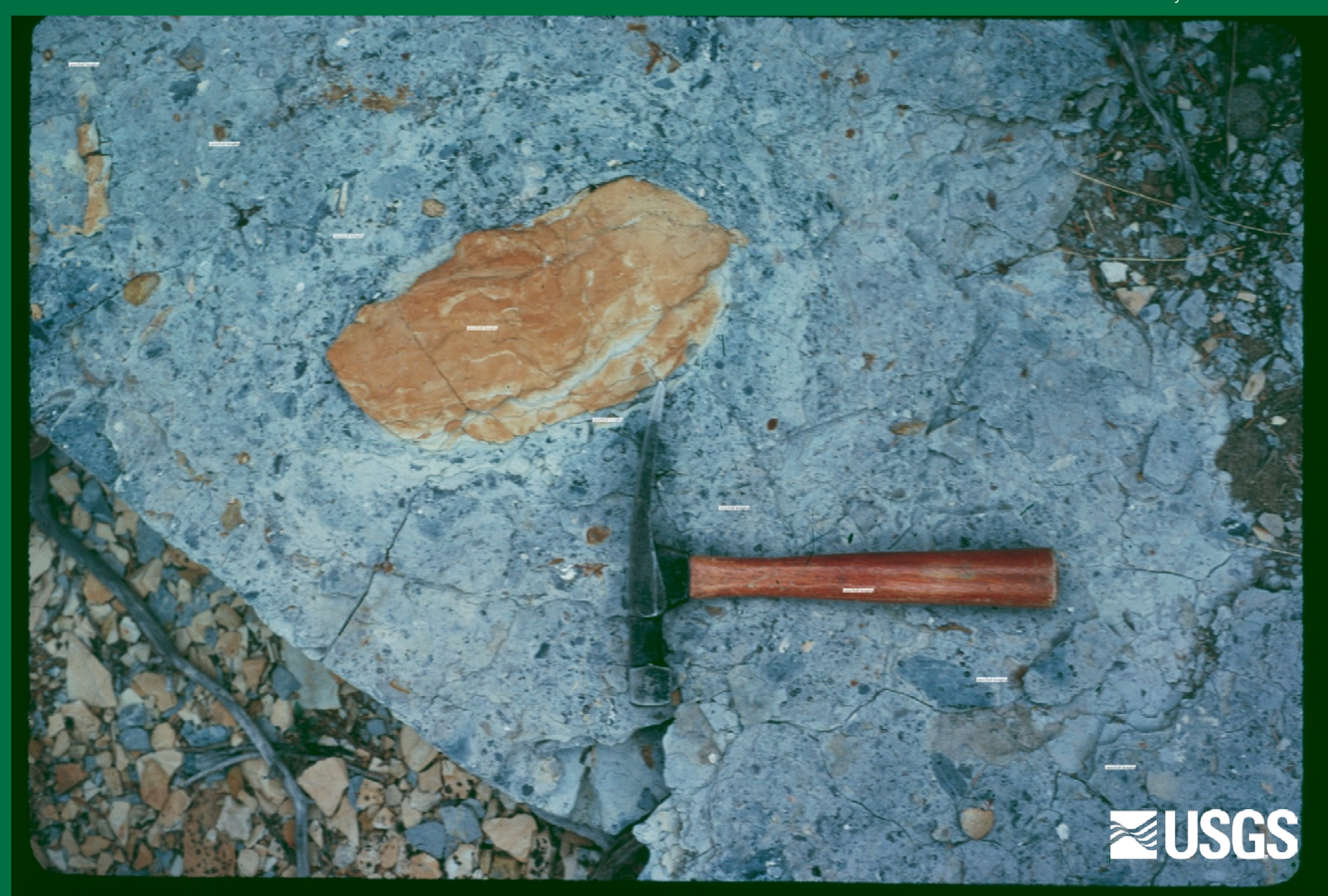

Bradley (1931, p. 28) noted the occurrence of "shale breccias" or oil shales that "contain as inclusions many comparatively large angular fragments or flakes of more or less similar rock, which are clearly derived from the breaking up of a bed elsewhere." 


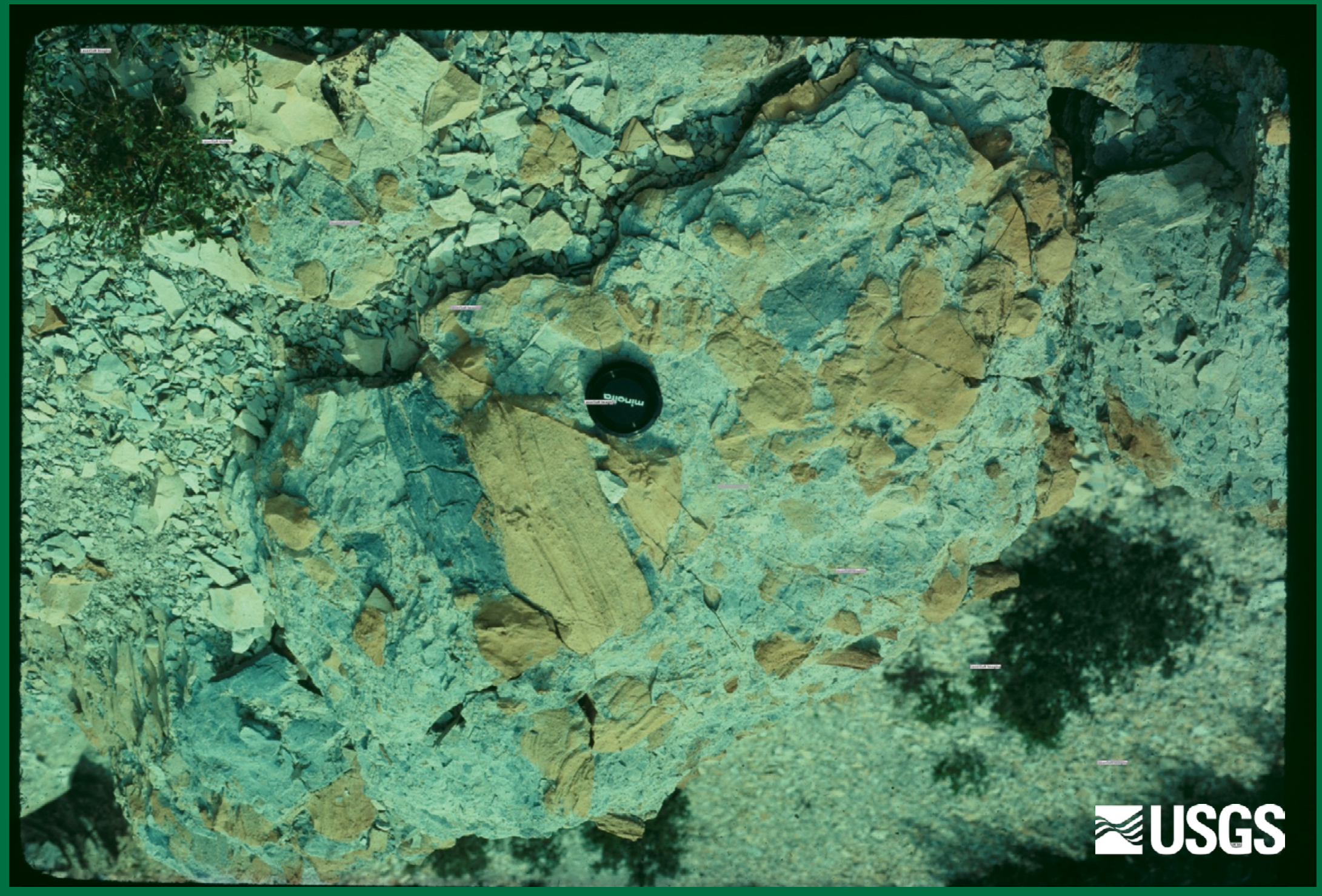

Bradley (1931) also noted that the boundaries of the fragments, some laminated, were commonly sharply defined indicating that they were lithified prior to being exhumed and incorporated into the breccias. 
Dyni (1981) and Dyni and Hawkins (1981) studied these mass-movement deposits in core from the central part of the basin and attributed some of them to deep-water turbidity currents.

Dyni (1981) and Dyni and Hawkins (1981) estimated 4050 percent of the lower part of the Parachute Creek Member in the central part of the basin consisted of "blebby oil shale."

Note the grading in the blebby oil shale bed in the upper right, from abundant large marlstone fragments at the base to kerogen in a very fine-grained matrix at the top.

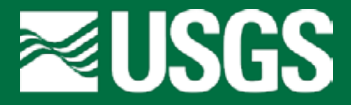

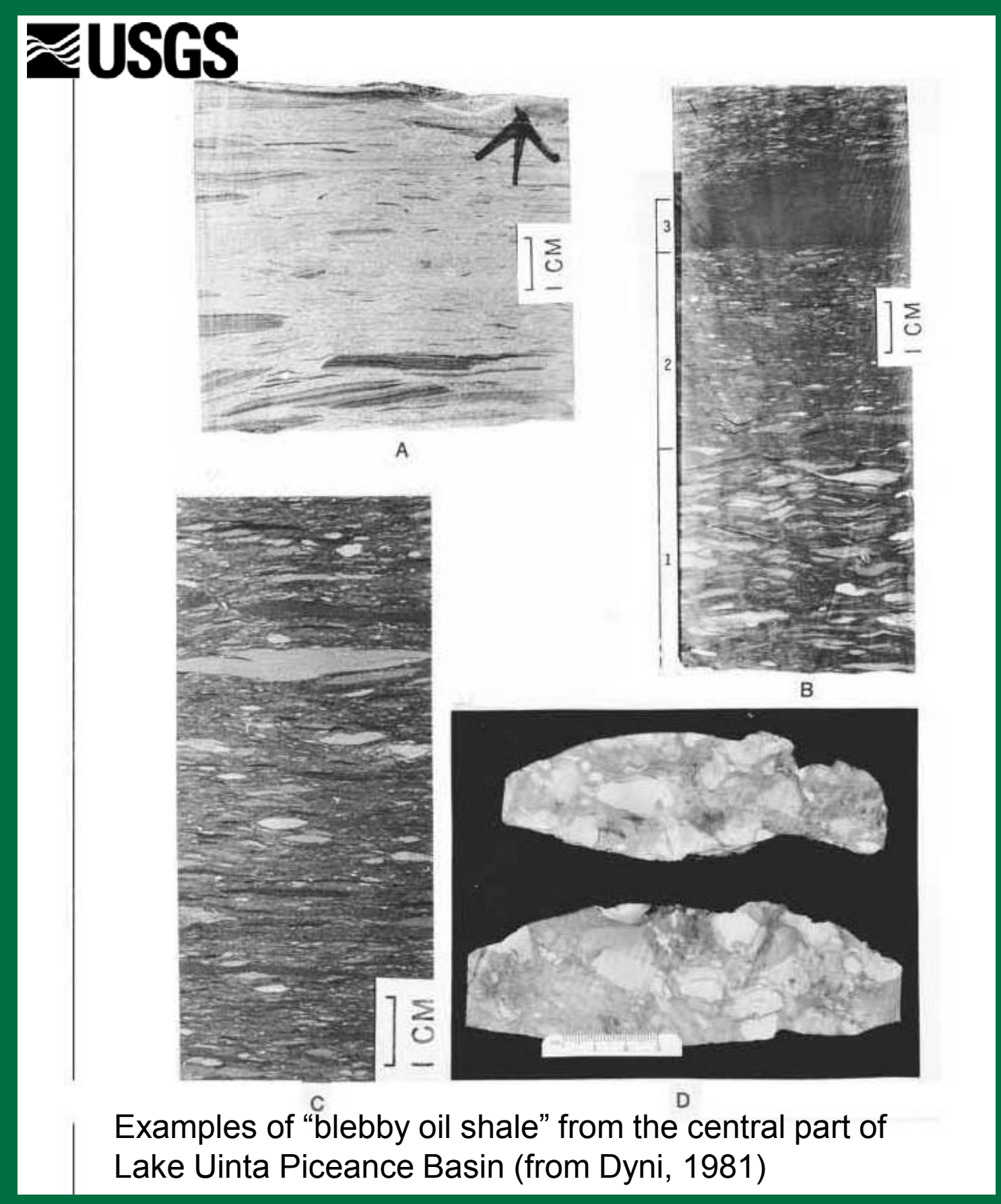




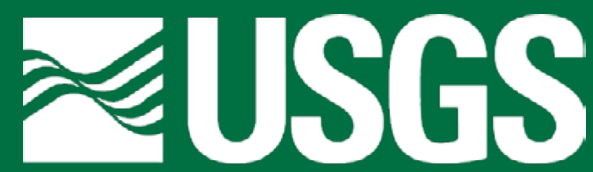

science for a changing world

Tanavsuu-Milkeviciene and Sarg (2012) studied the distribution of lacustrine facies in the Piceance Basin, and Iike Dyni (1981) and Dyni and Hawkins (1981), they found an increase in oil shale that was affected by mass-movement processes toward the central part of the basin. 


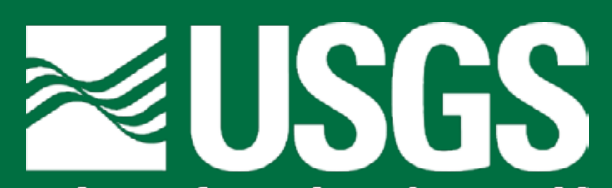

science for a changing world

\section{Here we attempt to build on the excellent work of these previous authors by placing mass- movement deposits into a detailed spatial and temporal framework}




\section{Data sources}

- Photos from nine coreholes that are housed at the U.S. Geological Survey Core Research Facility in Lakewood, Colorado, were examined for bedding features. The photos are available online at the Core Facility's Web Site.

- Outcrop sections were measured and described by the authors. All of the sections have been published, but thickness of individual beds were not reported. Thickness values were obtained from the original descriptions in field notebooks.

\section{₹USGS}




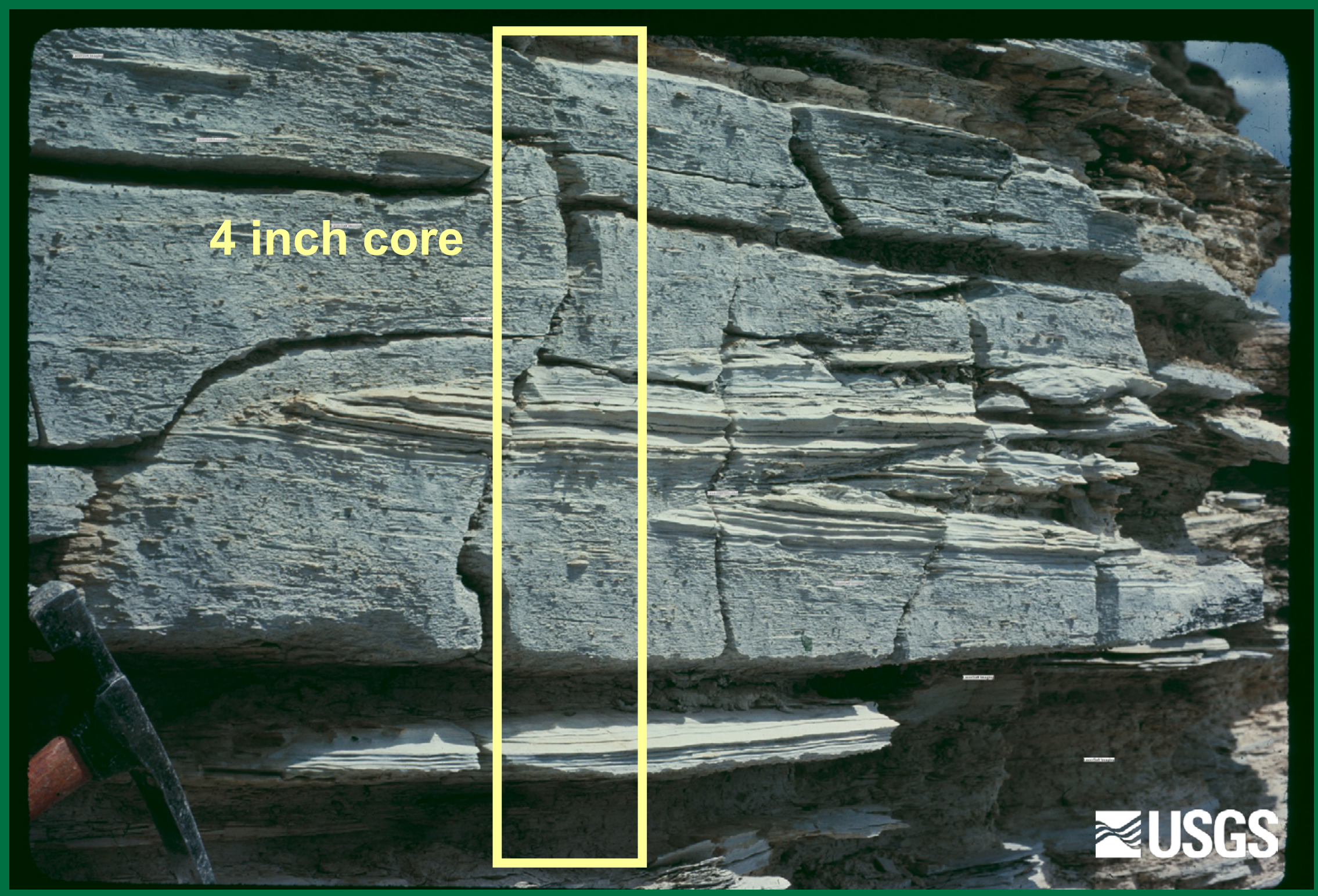

Mass-movement deposits commonly incorporated large blocks of laminated oil shale that appear to have been largely lithified prior to redeposition. These blocks can look like laminated intervals in core. 


\section{₹USGS}
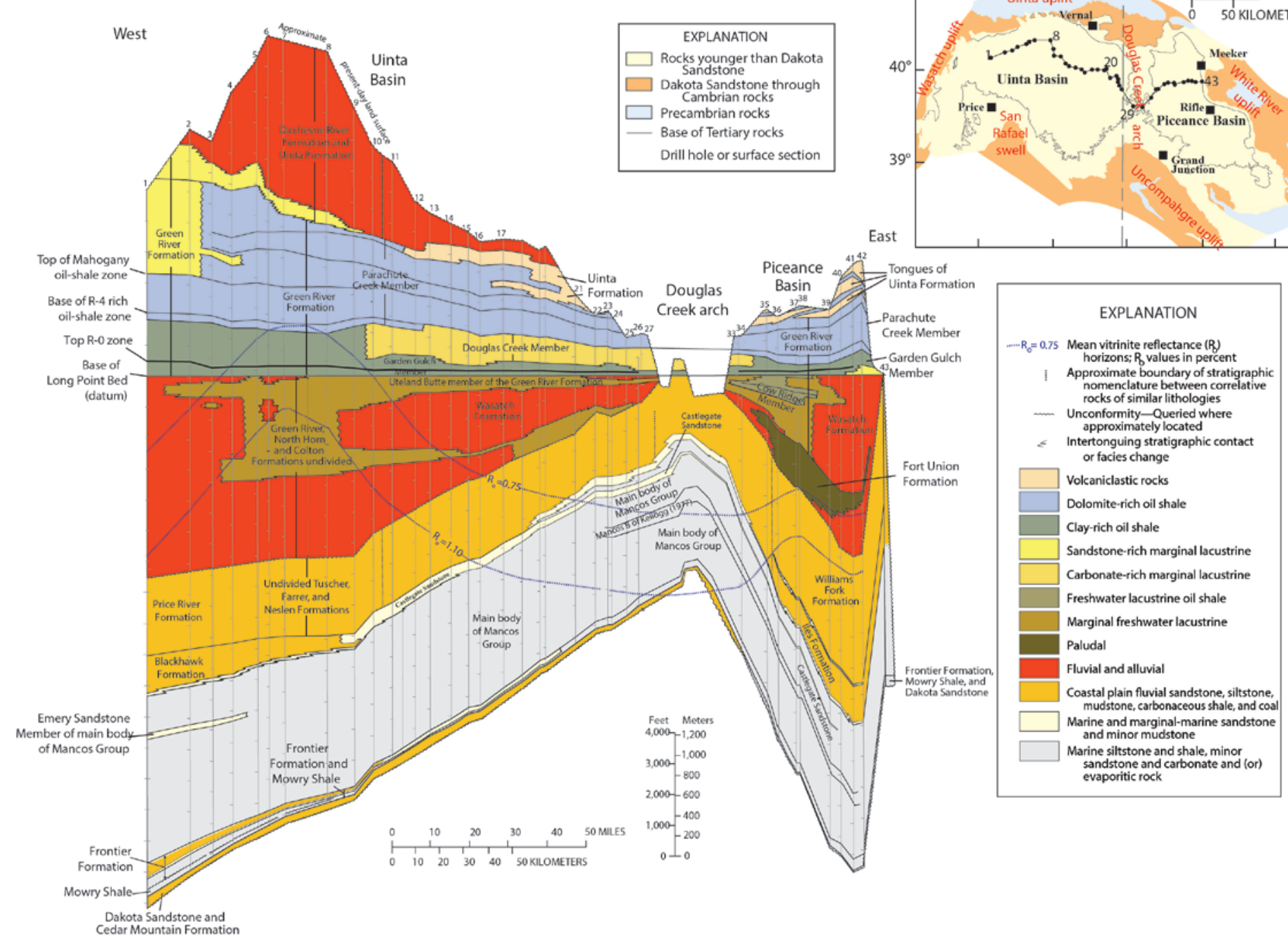

West-east cross section across the Uinta and Piceance Basins and the Douglas Creek arch. 
Lake Uinta began as a freshwater lake (Cow Ridge Member), became increasing saline during the illitic phase (Garden Gulch Member), finally becoming a carbonateand saline-mineral precipitating lake (Parachute Creek Member). Infilling with volcaniclastics began in the latter part of the carbonate phase (light purple).

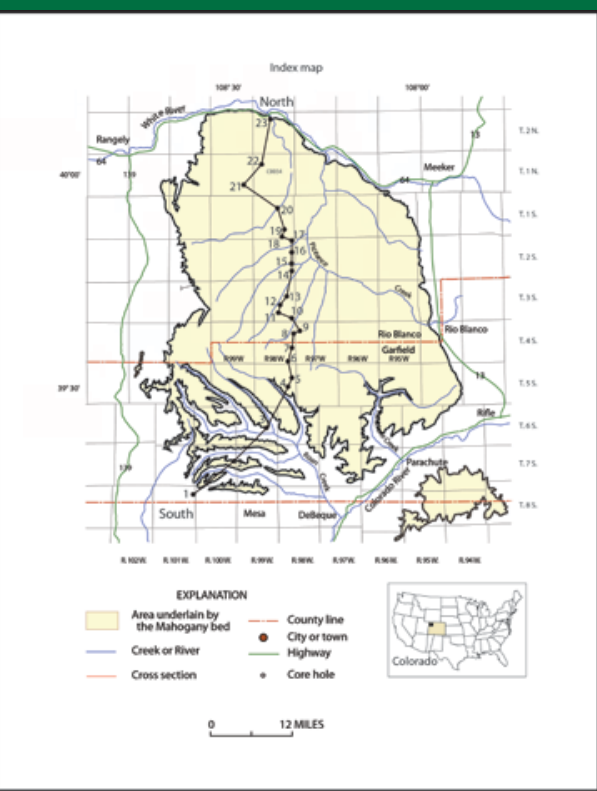

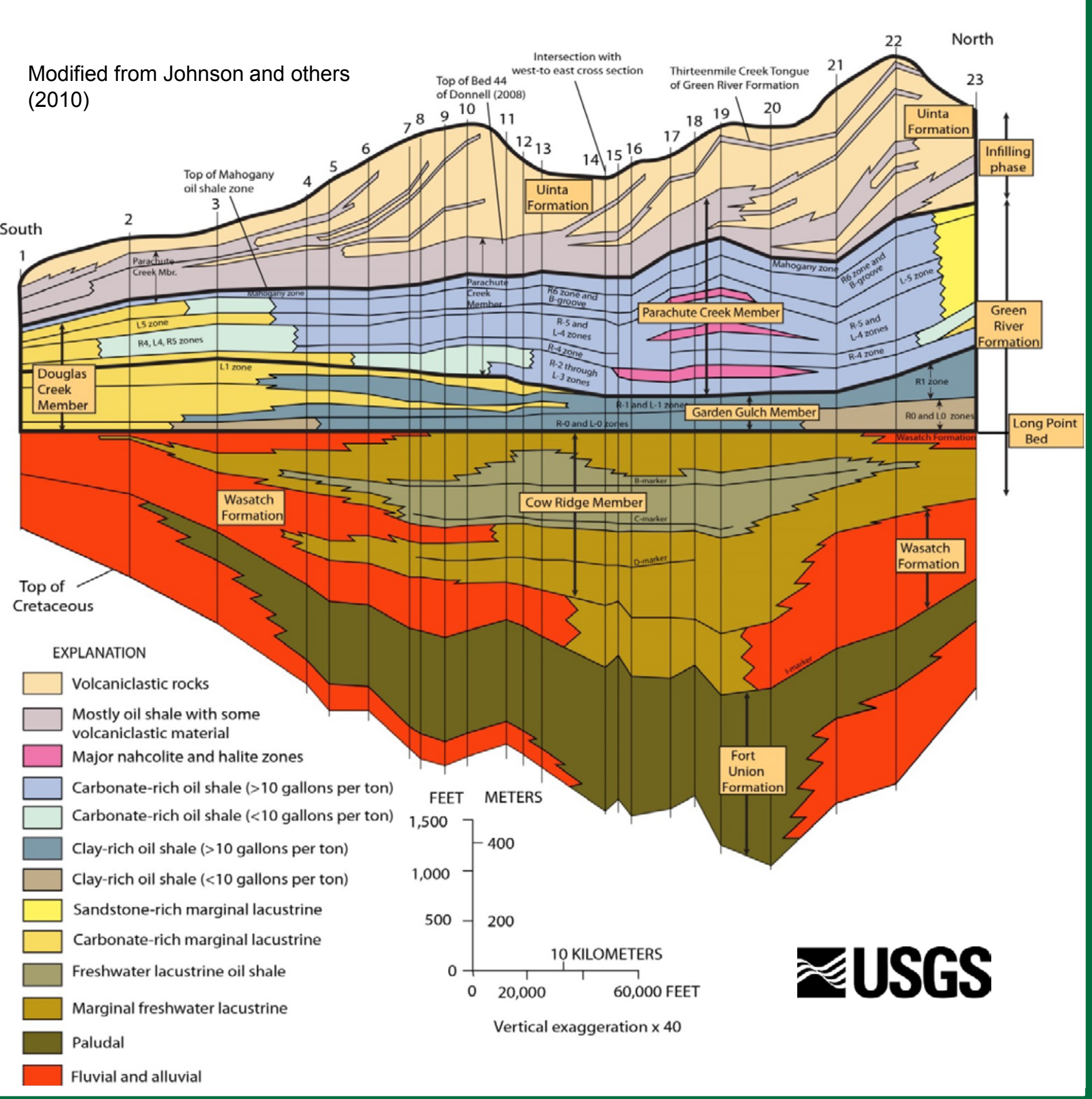

South to north cross section 
Oil yields using the Fischer assay method are shown on the subsequent slides. Pictured is a Fischer assay retort.

Products collected: condensed oil condensed water spent rock

Reported values:

weight percent (wt\%) oil wt $\%$ water wt $\%$ loss (gases) oil density coking tendency

Wt $\%$ oil is converted to gallons per ton oil here.

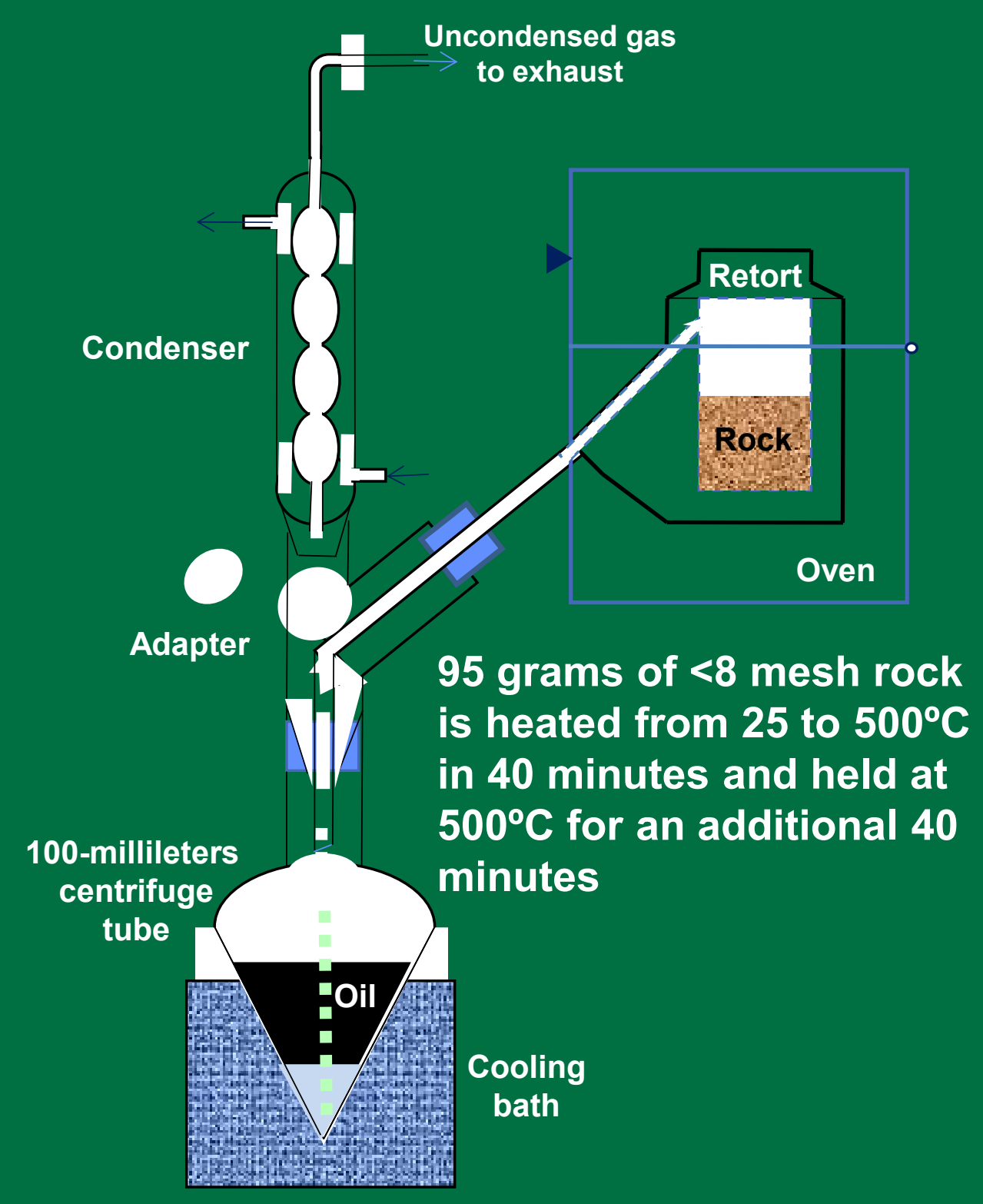




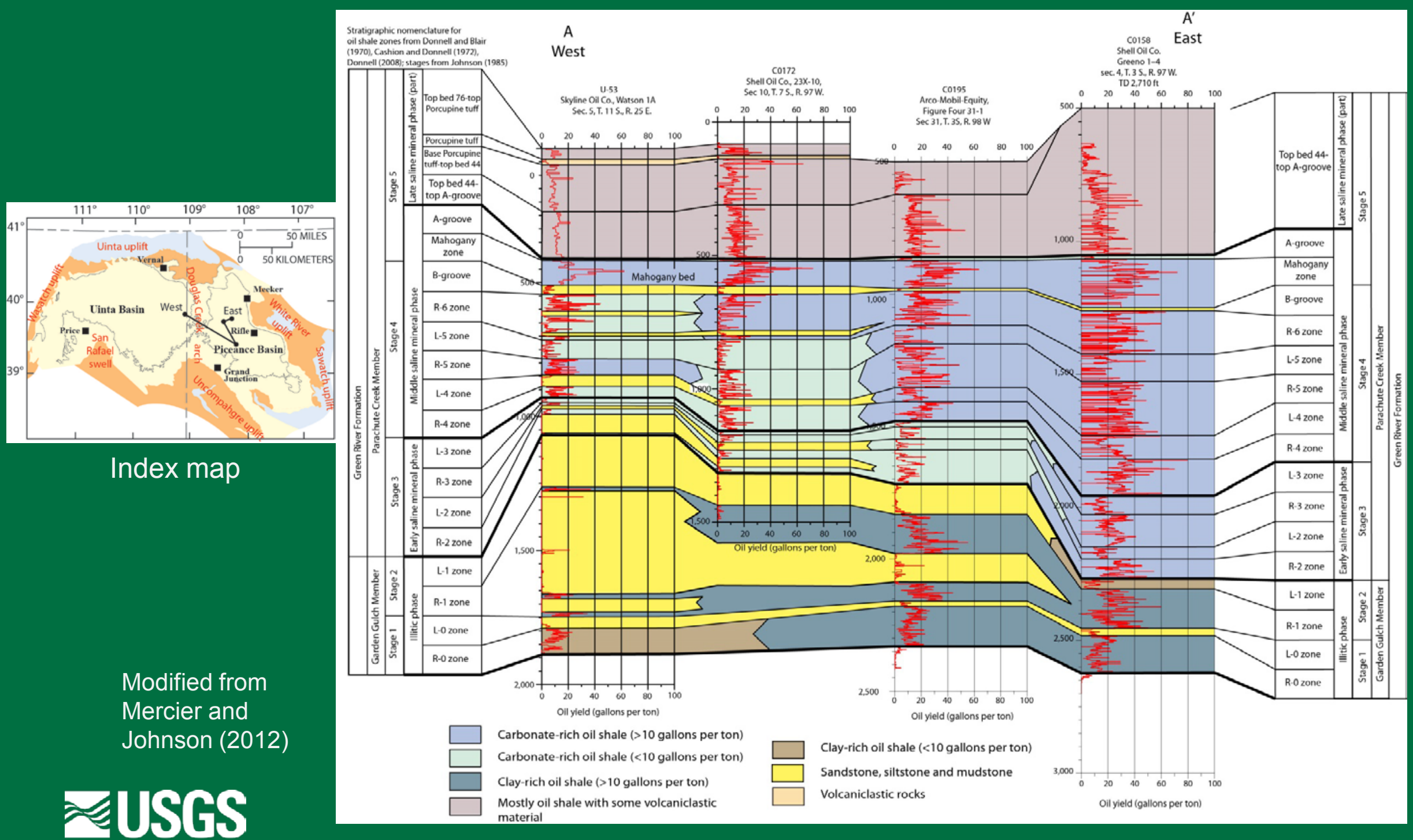

The Garden Gulch and Parachute Creek Members are subdivided into 16 recognized rich (R) and lean (L) oil-shale zones. Red graphs are gallons per ton oil using Fischer Assay. Maps showing percent of mass-movement deposits in each zone were constructed. The next slide is a paleogeographic map for the end of the preceding freshwater phase. 


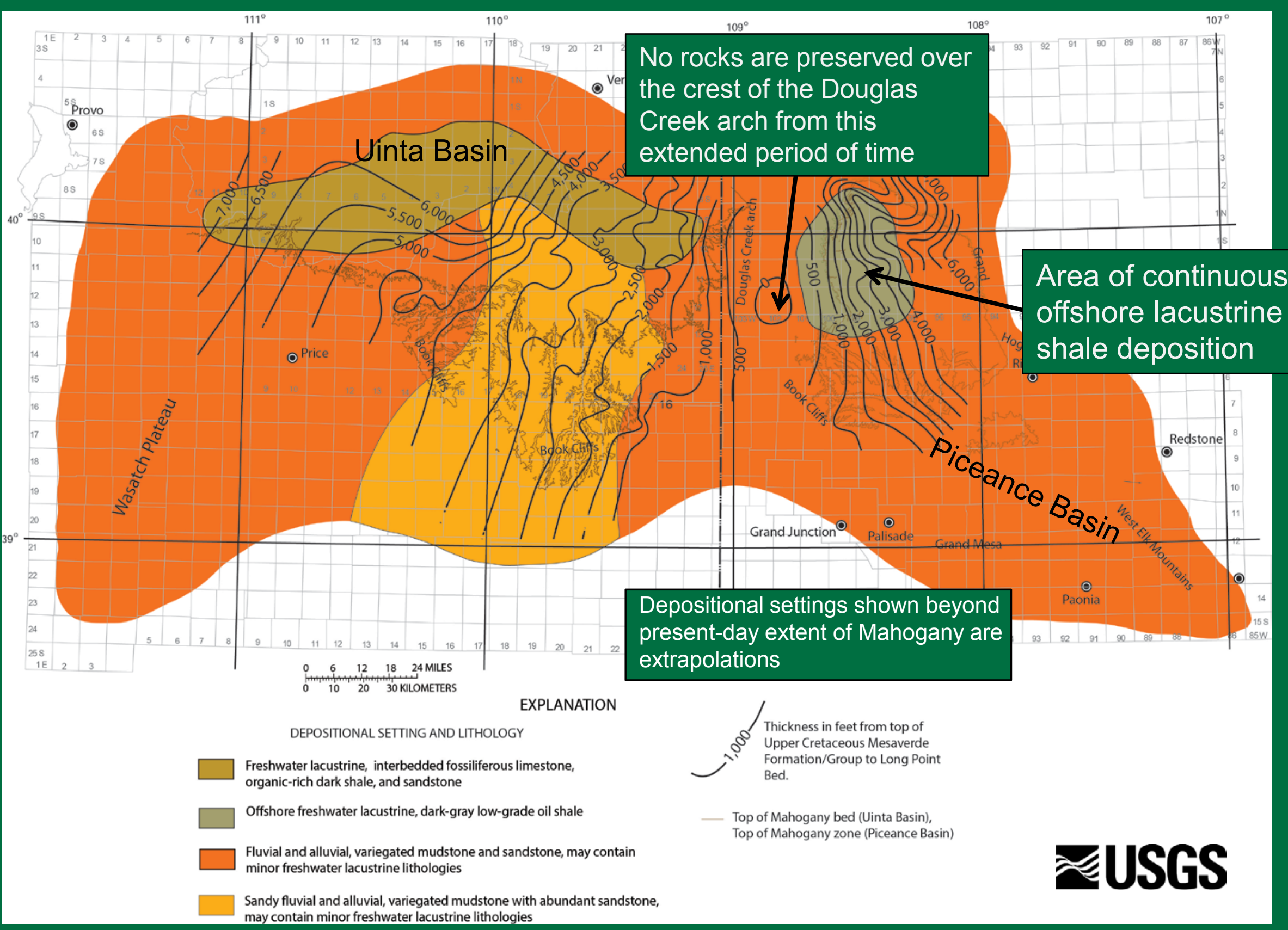

Extent of freshwater lakes just prior to the development of Lake Uinta. Isopach map is from the top of the Cretaceous to the top of the freshwater phase. 


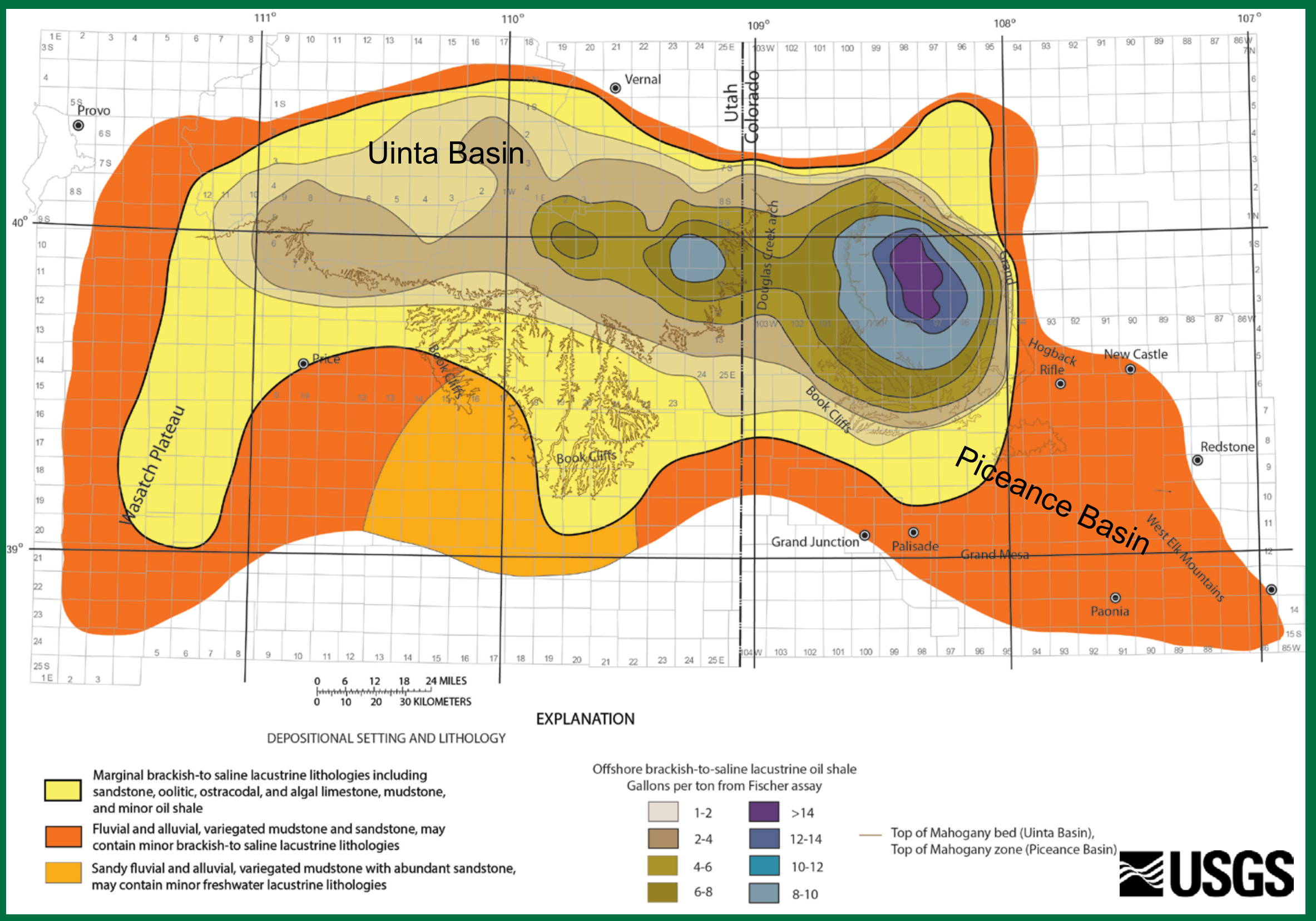

Lake Uinta formed as a result of a major transgression-the Long Point transgression. This map shows Lake Uinta during maximum transgression when low-grade oil shale was deposited over large parts of the Uinta and Piceance Basins. Oil yield in gallons per ton Fischer Assay is shown. 


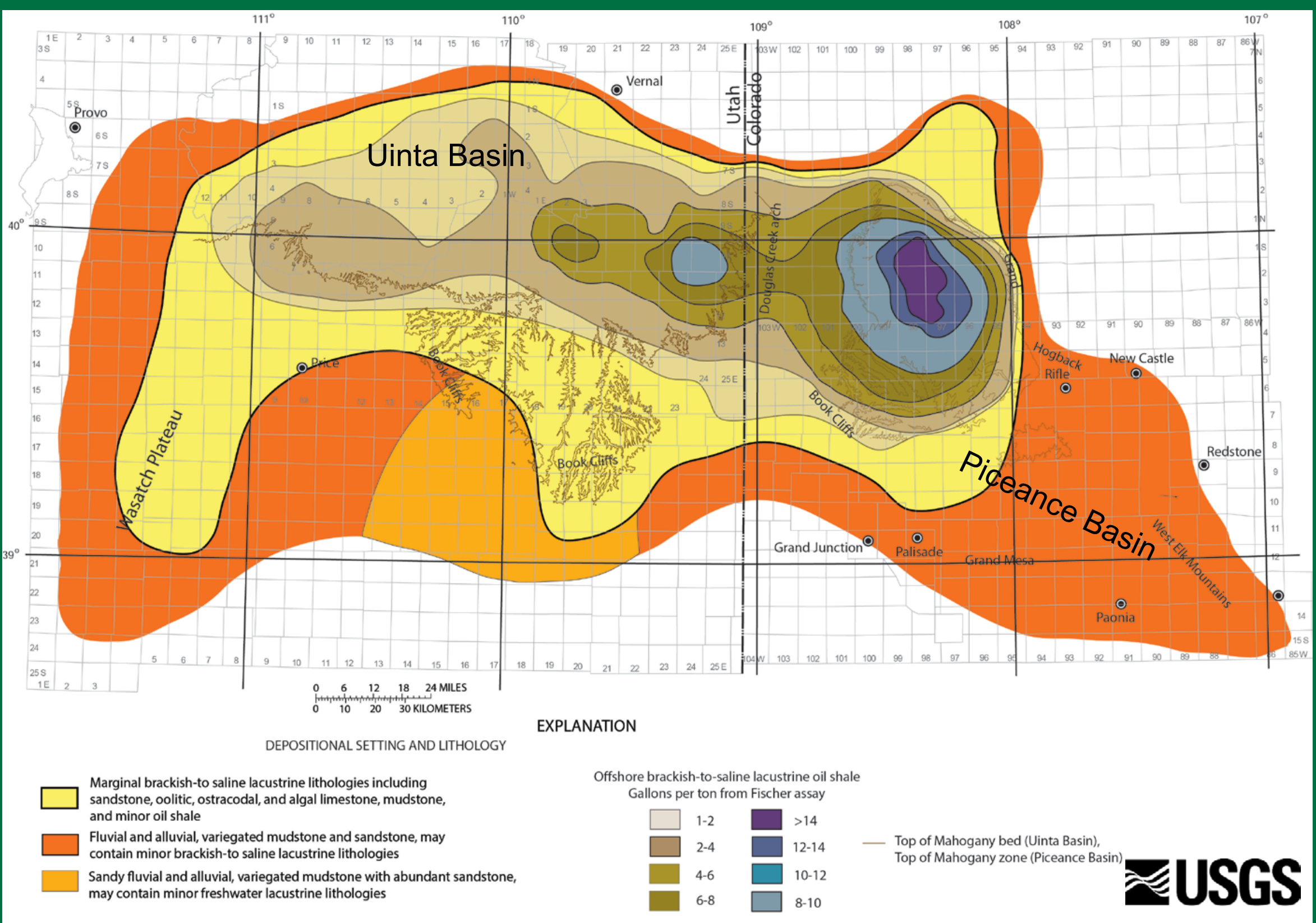

Subsequent slides progress through the development of the rich (R) and lean ( $L$ ) oil shale zones in the Piceance Basin showing the distribution of mass-movement deposits. 


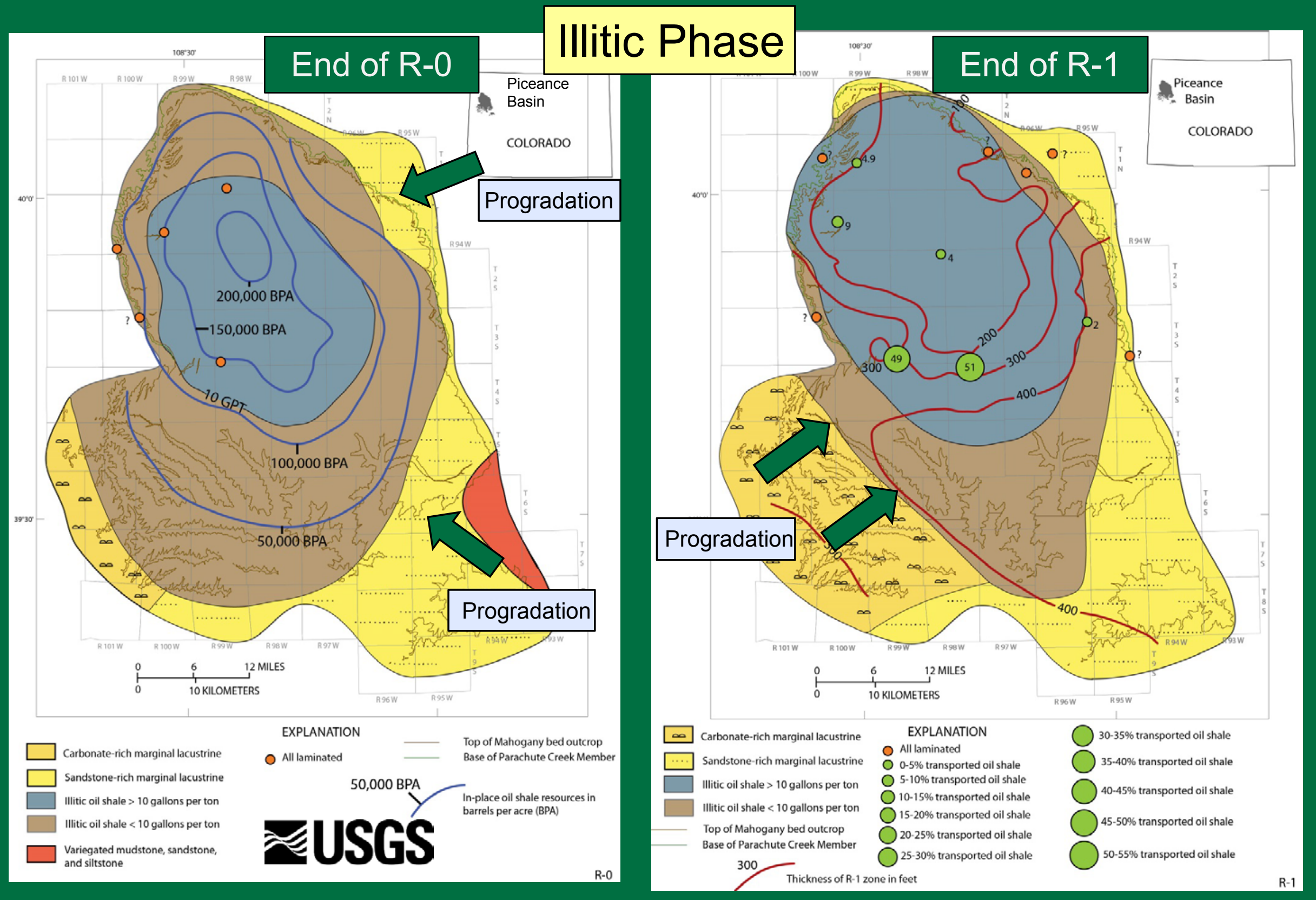

Marginal shelves prograded (green arrows) from the southeast and northeast during R-0 time and from the southwest during R-1 time. No mass-movement deposits were identified in the R-0 zone, whereas mass-movement deposits accumulated at the base of the expanding shelf during R-1 time. 


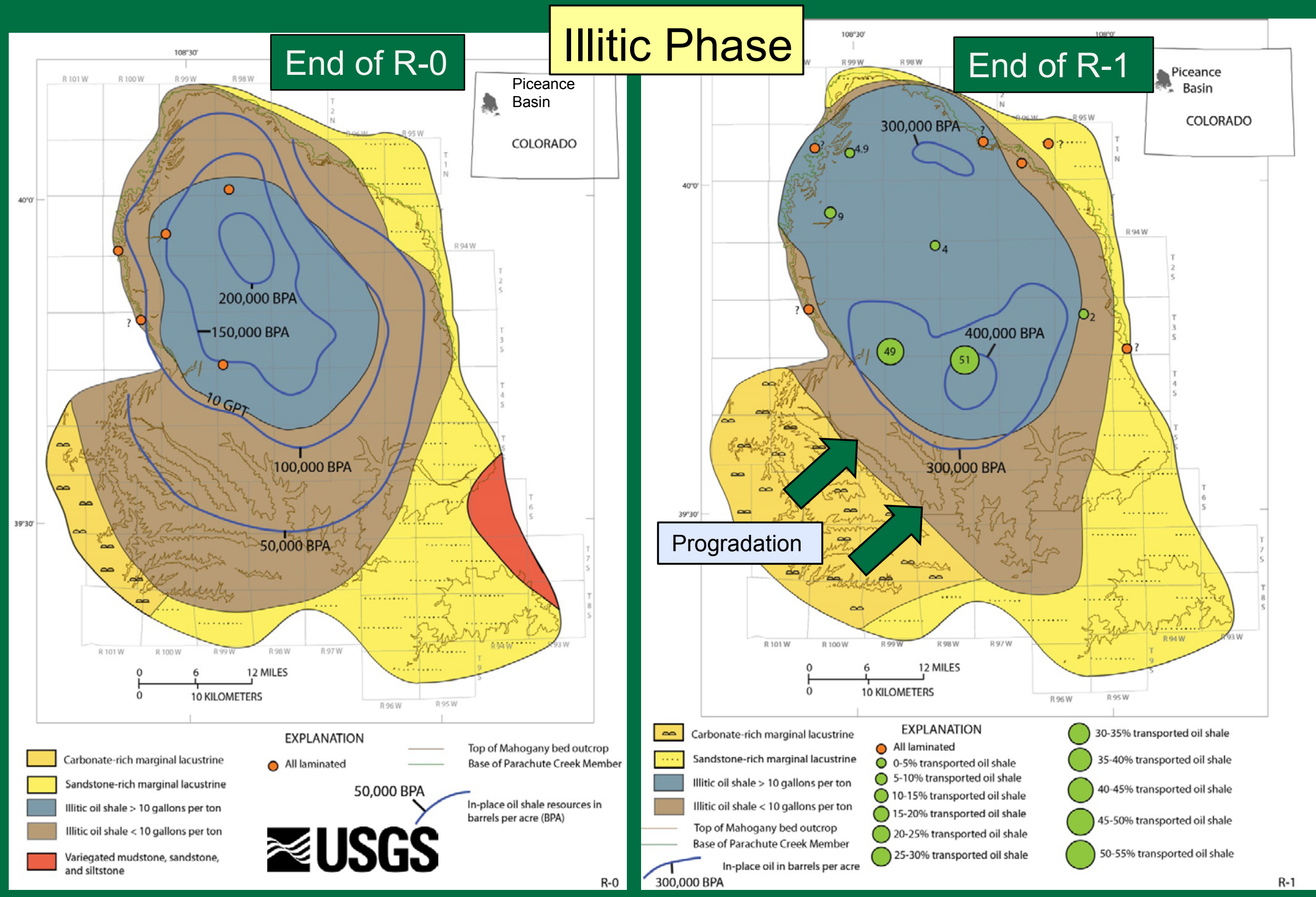

Total organic matter, measured by barrels of oil per acre (BPA), increases toward the center of the basin in the R-0 zone, which contains no mass-movement deposits, whereas total organic matter is greatest where mass-movement deposits are greatest in the R-1 zone. 


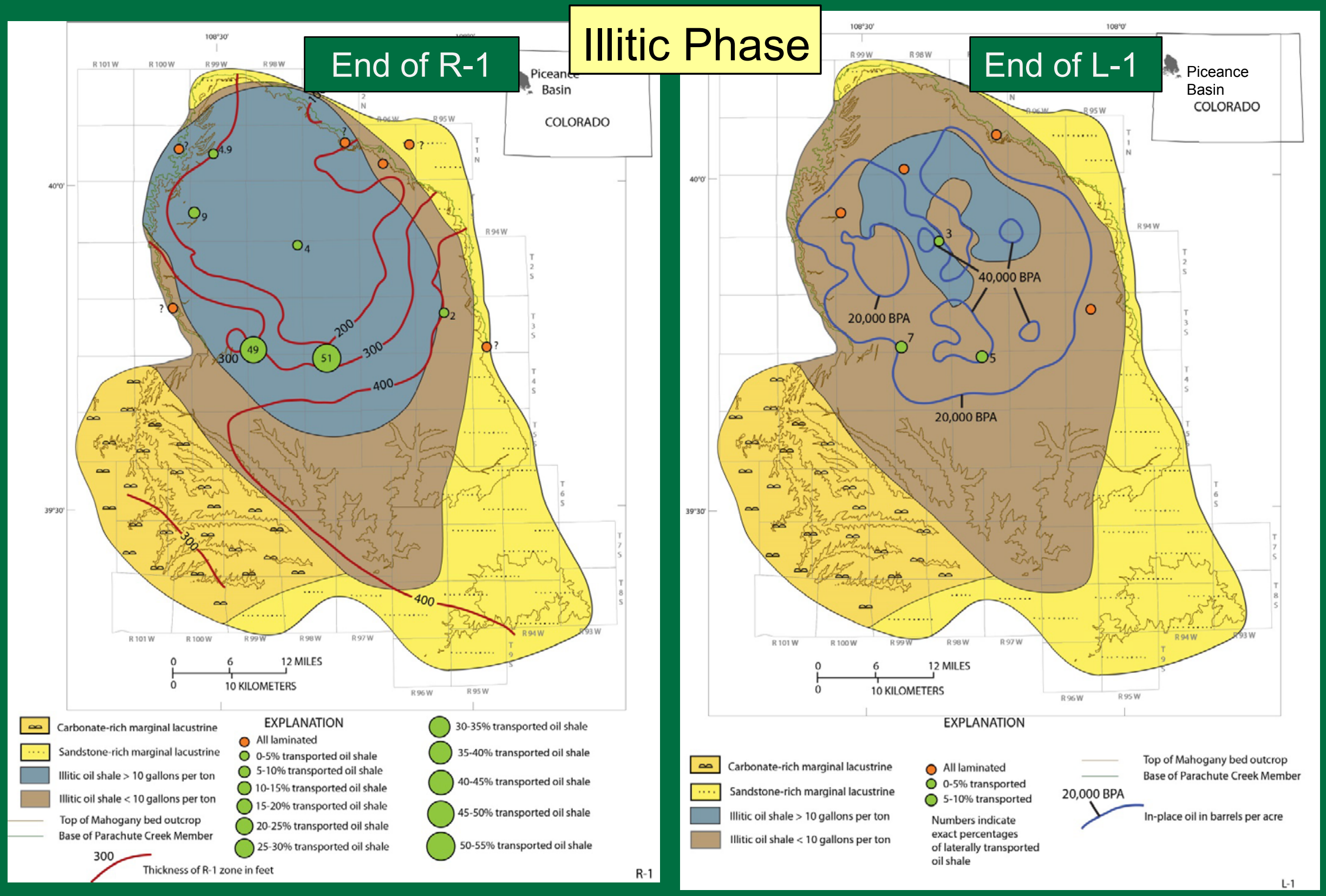

Mass-movement deposits are much less common in the L-1 lean zone than the underlying richer R-1 zone. 


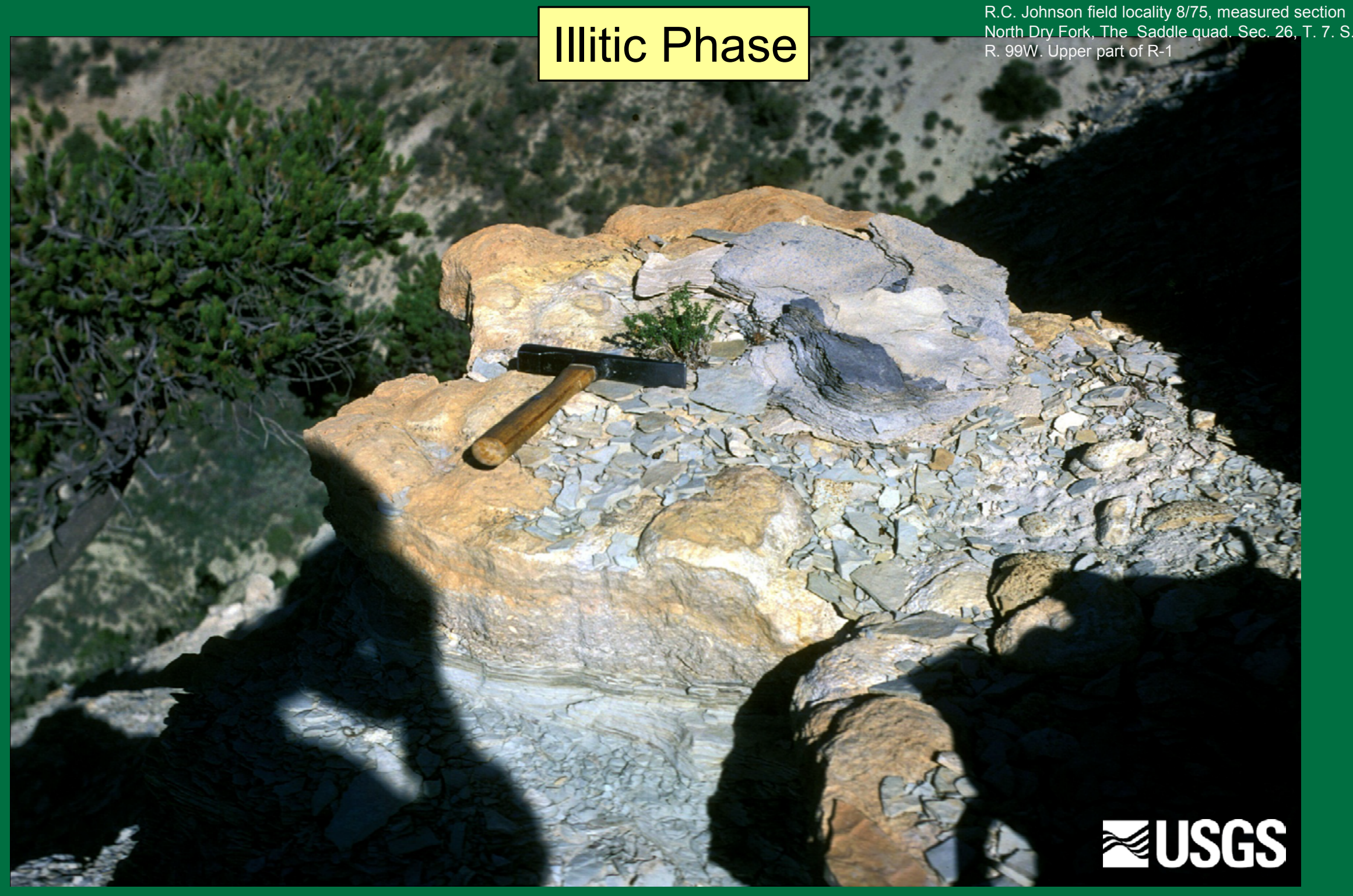

Oil-shale beds are preserved in marginal lacustrine environments, indicating that significant organic matter was accumulating there. Many of these beds occur above the bulbous structures on stromatolites that may have offered protection from lateral transport. This bed is in the R-1 zone. 


\section{Interpretation for $\mathbf{R}-\mathbf{1}$ zone}

- Mass-movement deposits accumulated at the slope between marginal shelves and the deep lake area.

- The mineral matter and organic matter that made up the massmovement deposits originated on the marginal shelves and slope on the southeast and southwest parts of the lake.

- Brines that formed on the marginal shelves may have been incorporated into the massmovement deposits.

- Brines may also have formed on the northeast and north margins of the lake, but mass-movement deposits were rare there.

\section{Illitic Phase}

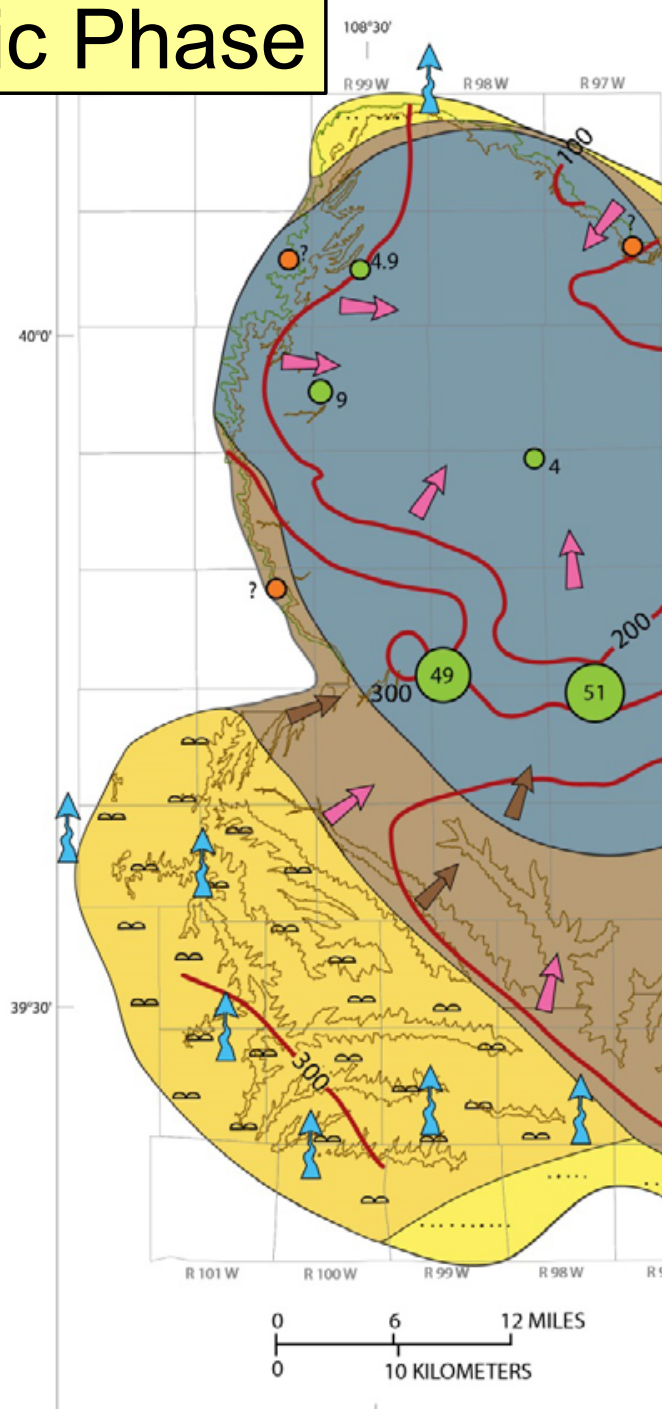

Carbonate-rich marginal lacustrine Sandstone-rich marginal lacustrine Illitic oil shale $>10$ gallons per ton Illitic oil shale $<10$ gallons per ton Top of Mahogany bed outcrop Base of Parachute Creek Member 300
EXPLANATION

O All laminated

0-5\% transported oil shale 5-10\% transported oil shale 10-15\% transported oil shale $15-20 \%$ transported oil shale

20-25\% transported oil shale 25-30\% transported oil shale
1080

Piceance

Basin

COLORADO

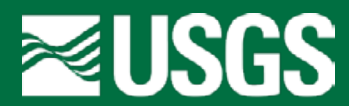

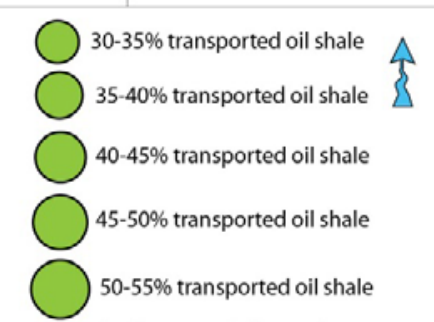

Movement of organic 


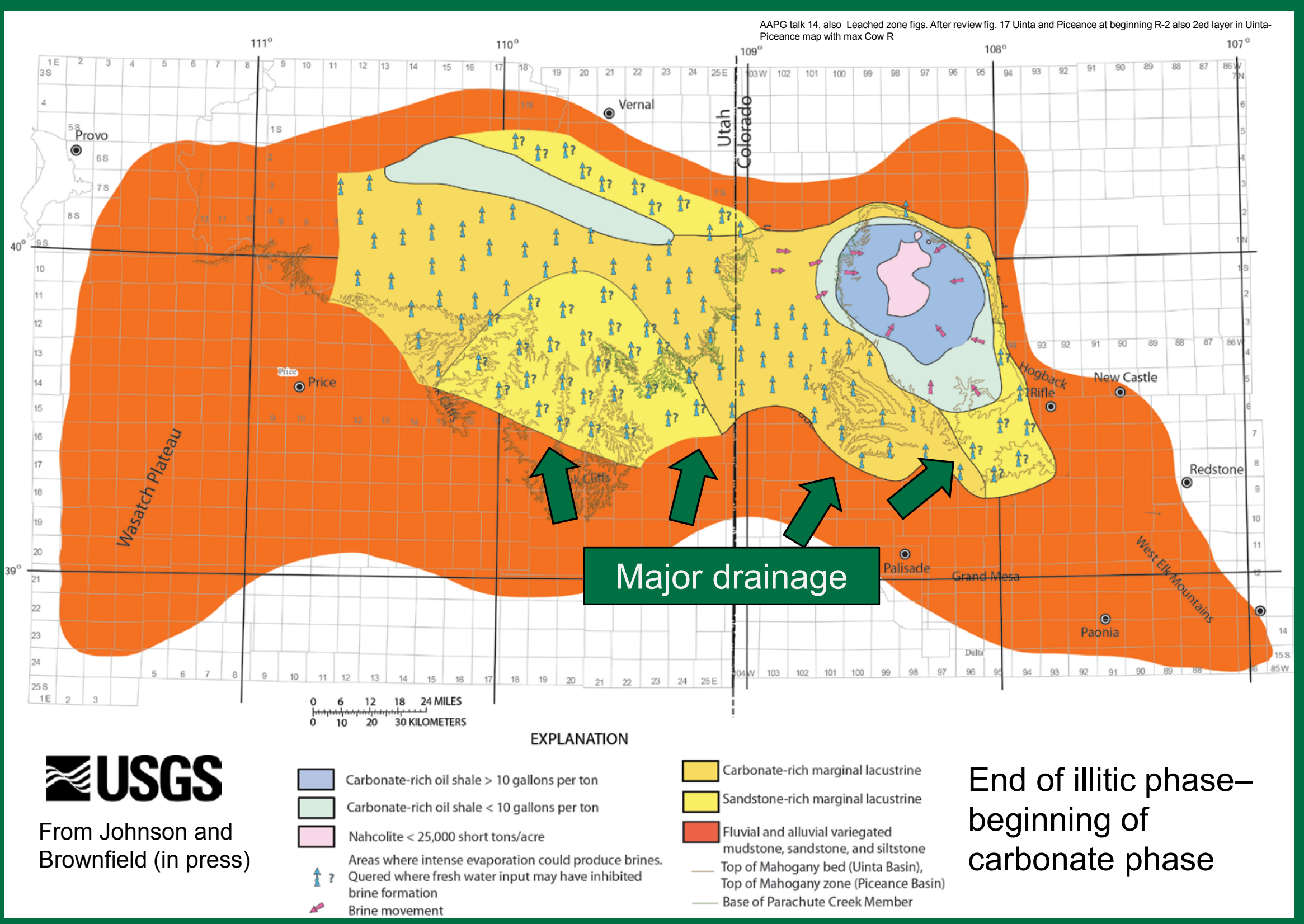

By the end of the illitic phase, offshore oil-shale deposition had been replaced by shallow-water shelf deposition throughout all but the deep trough of the Uinta Basin. Sediments from the southern Uinta Basin spilled over to create an expanding shelf along the southwest margin of the Piceance Basin. 


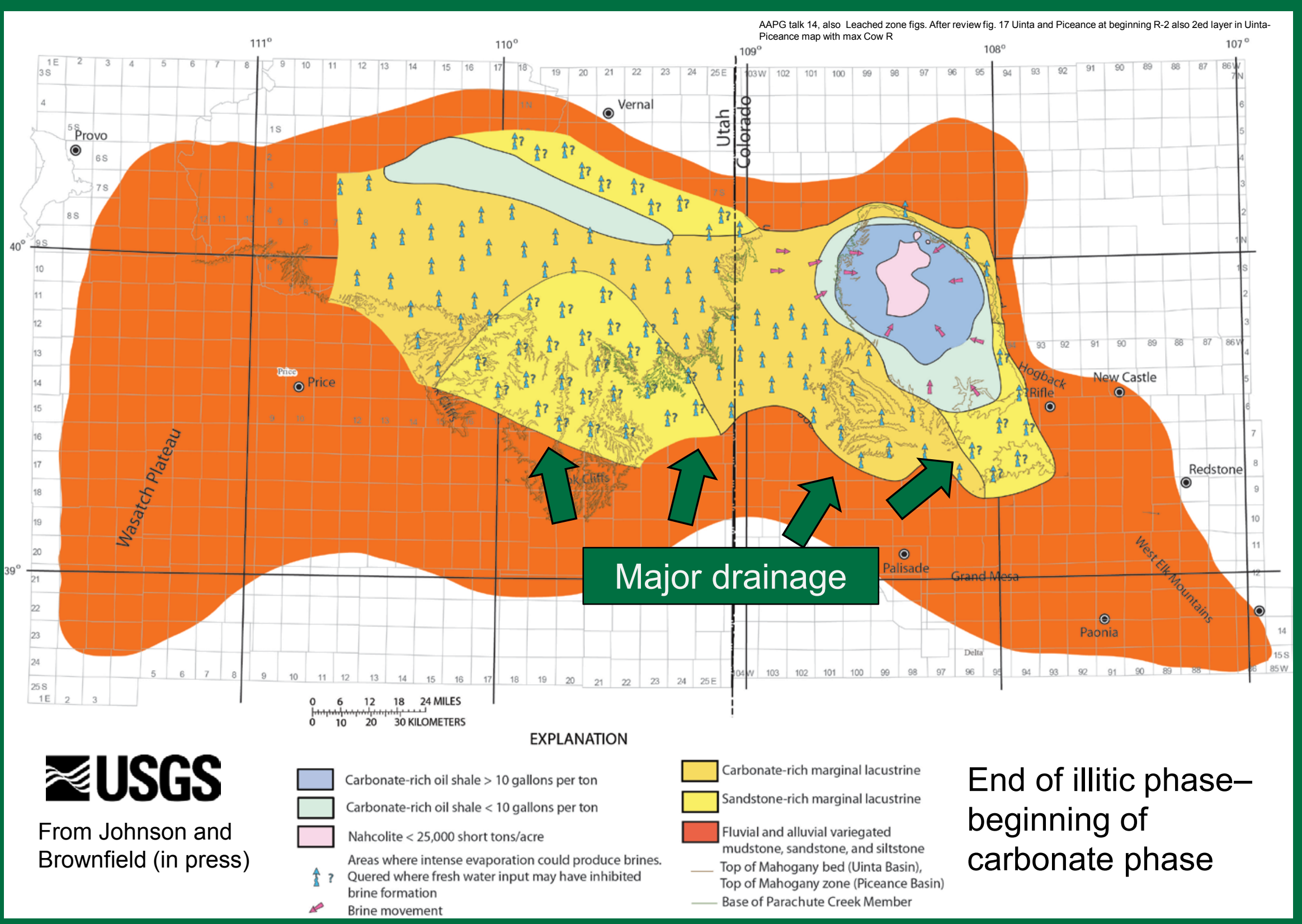

Many authors have stressed the importance of evaporation on lake-margin mud flats in producing concentrated brines (Smith, 1974, p. 77; Ryder and others, 1976; Eugster and Hardie, 1978; Surdam and Stanley, 1979; Johnson, 1985; Remy and Ferrell, 1989). 


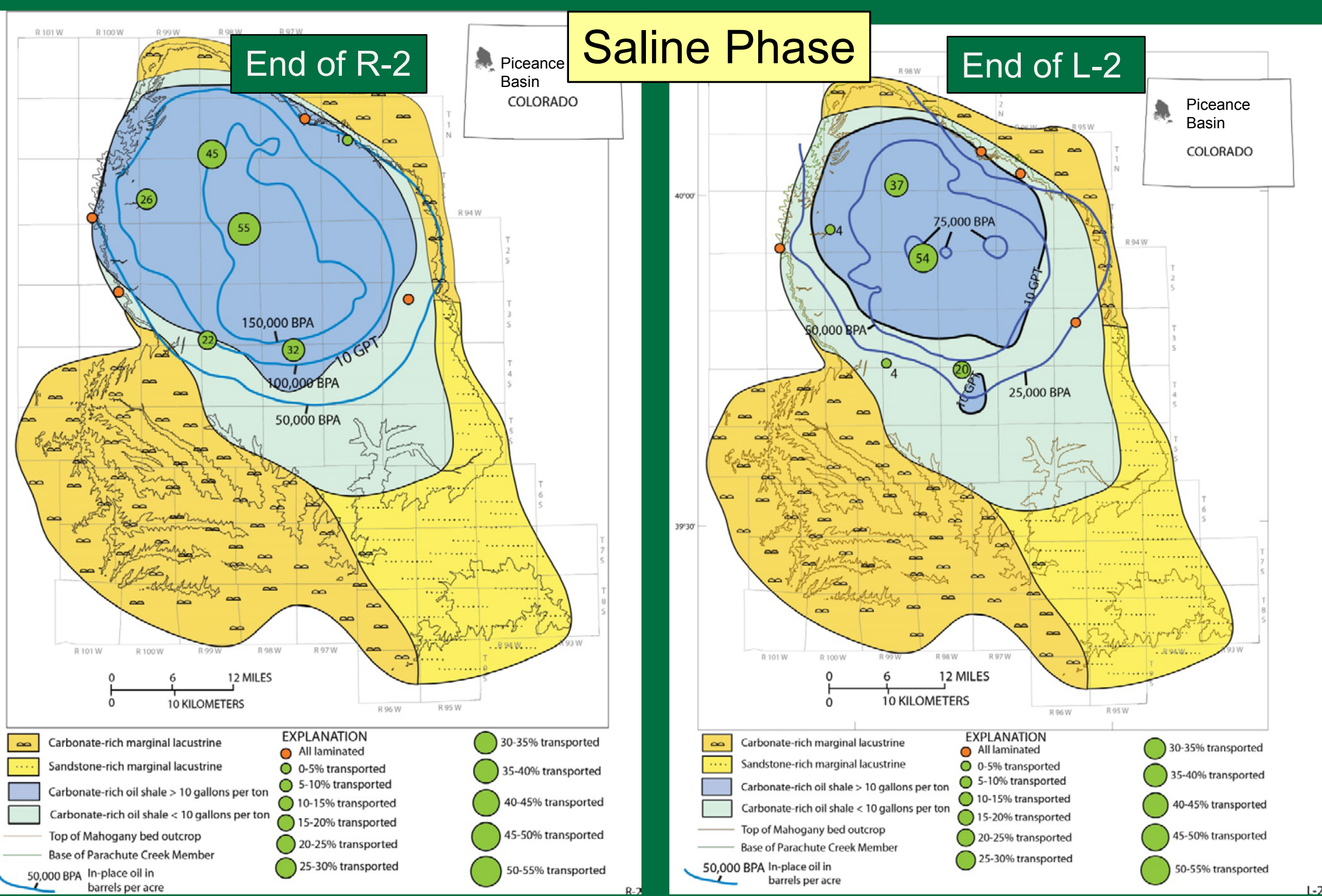

By the beginning of the carbonate and saline mineral phase of the lake (Parachute Creek Member, R-2 oil shale zone), shelf building had slowed. Mass-movement deposits now accumulated mainly in the central part of the lake. 


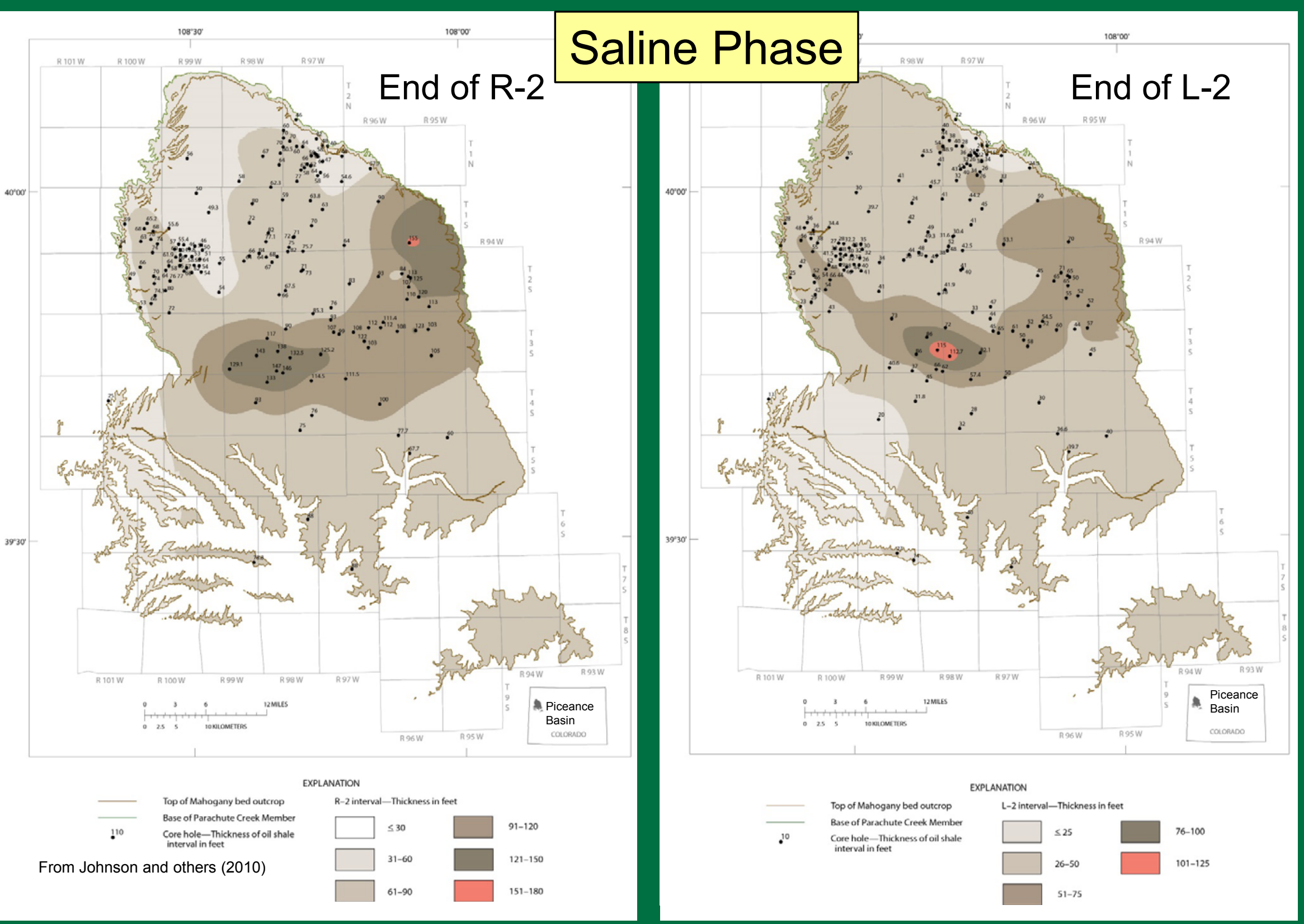

₹USGS Some shelf building continued during the early carbonate phase. The R-2 and L-2 zones are thickest at the base of the shelf. 


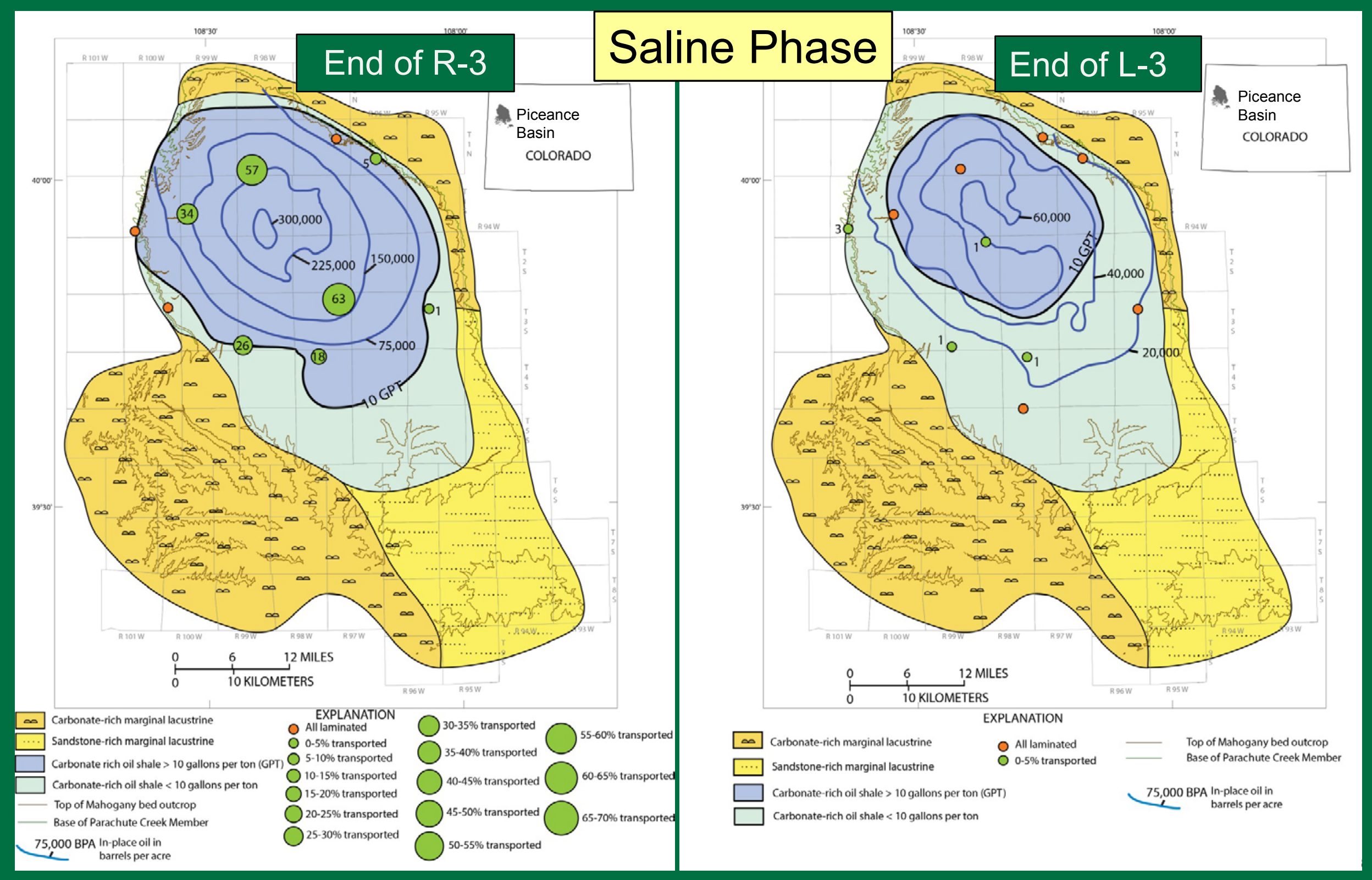

The R-3 zone is predominantly composed of mass-movement deposits in the center of the lake, whereas the overlying L-3 zone contains almost no mass-movement deposits. 


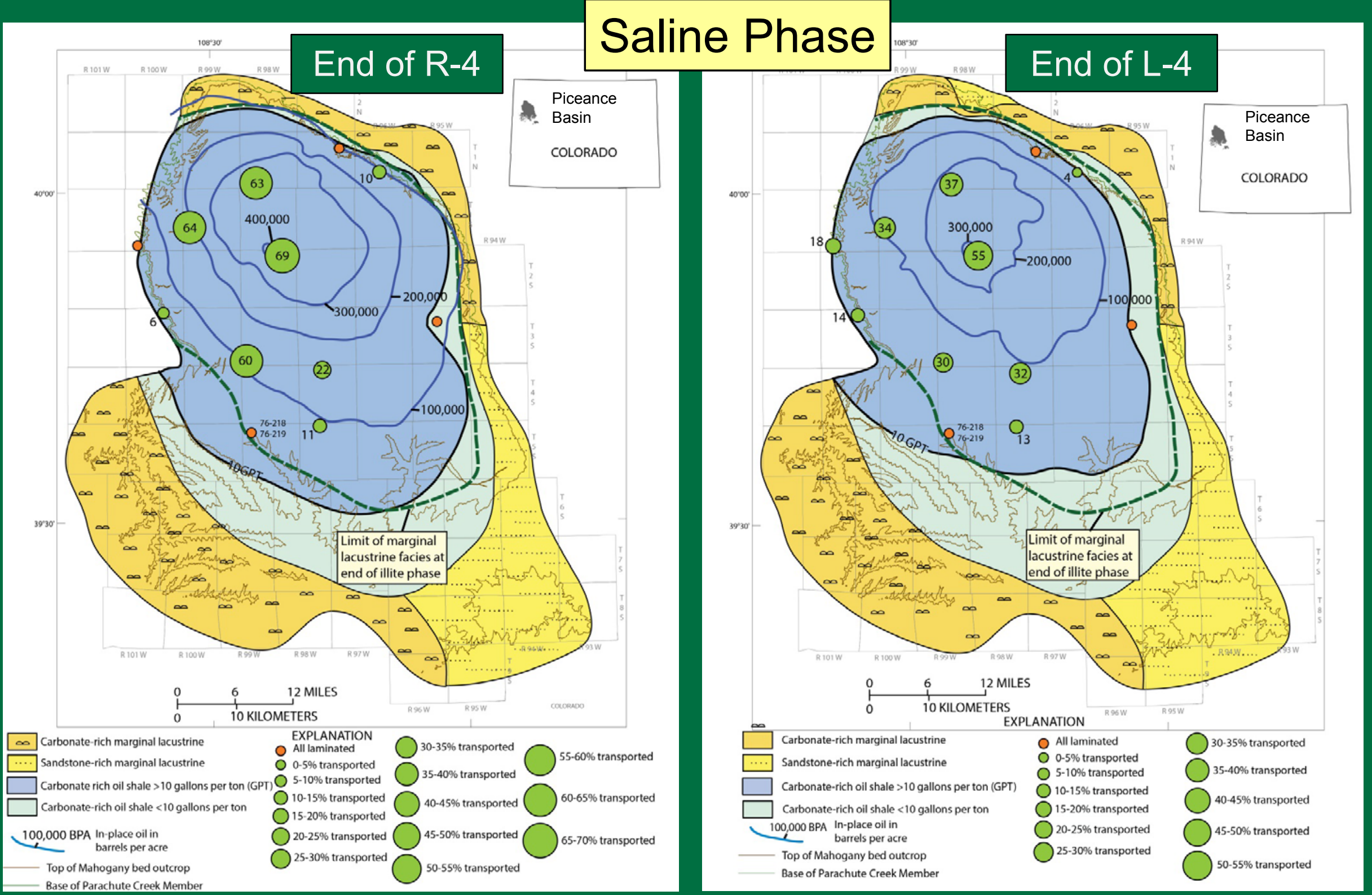

The lake began to expand over the marginal shelves in R-4 time. The rich R-4 zone is mainly composed of mass-movement deposits in the center of the lake, whereas mass-movement deposits are somewhat less in the overlying leaner L-4 zone. ₹USGS 


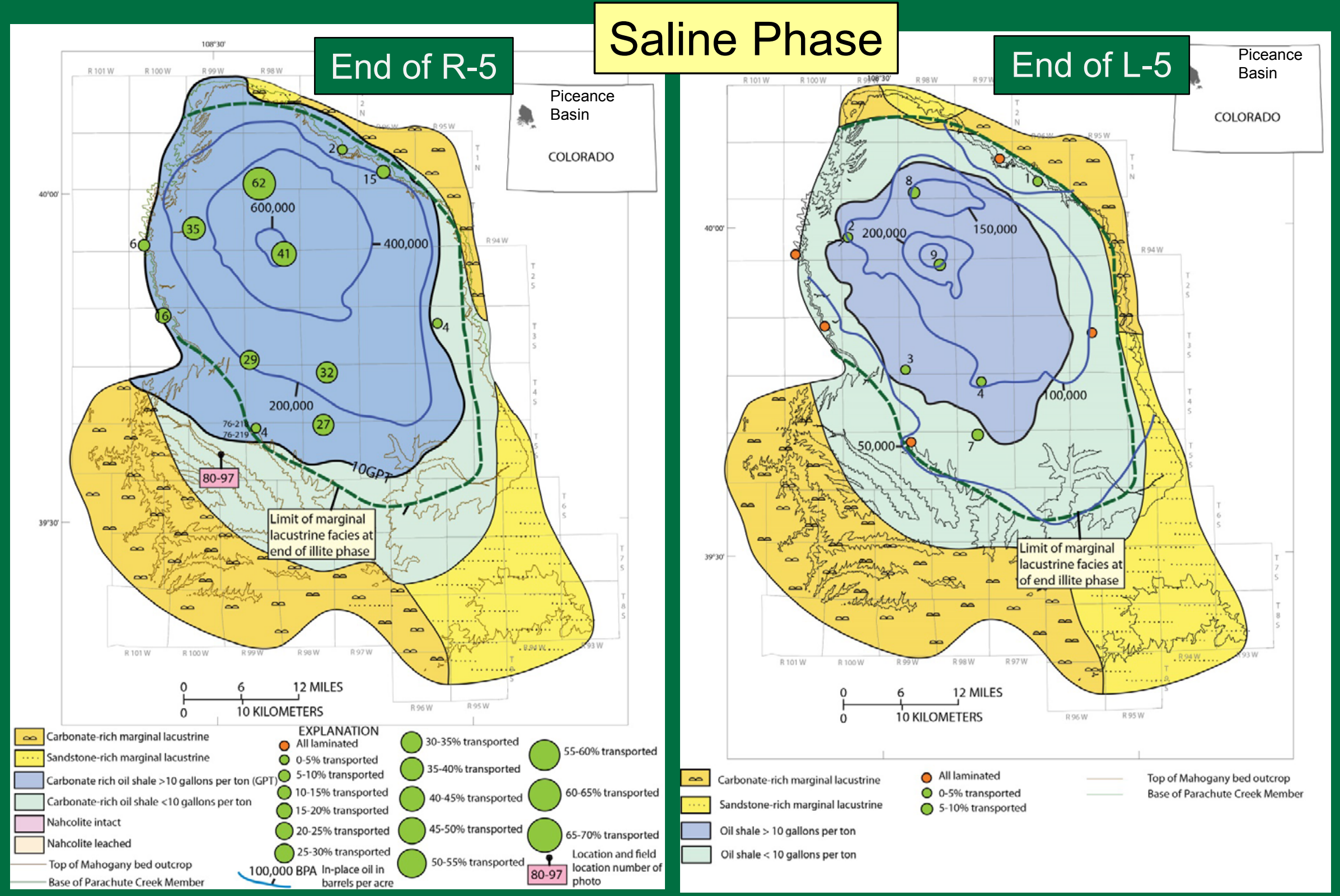

The R-5 zone contains abundant mass-movement deposits, whereas massmovement deposits are rare in the overlying leaner $L-5$ zone. 


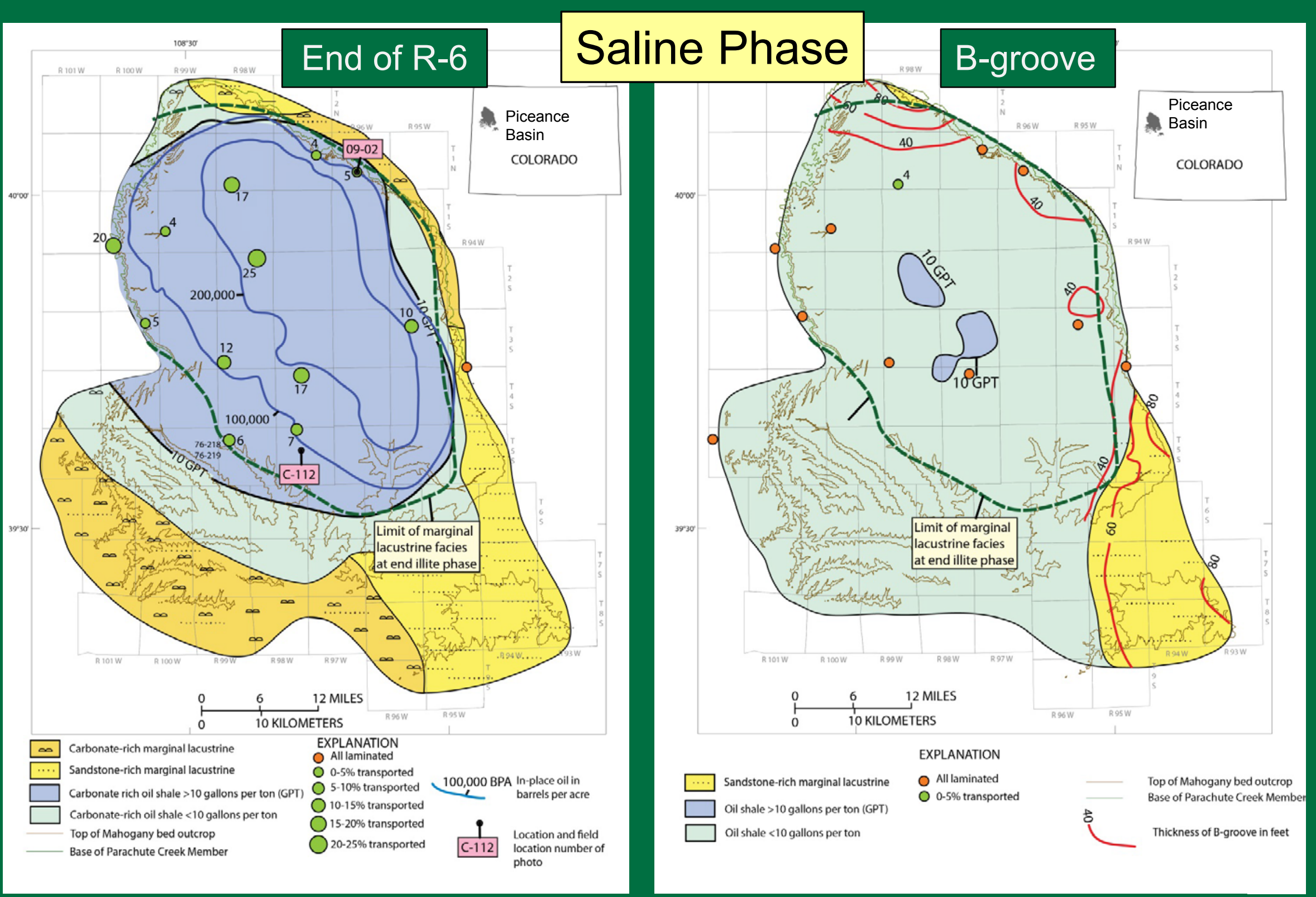

The percentage of mass-movement deposits progressively decreased as deepwater conditions continued to encroach on the marginal shelf during R-6 time. The overlying lean B-groove contains almost no mass-movement deposits. 


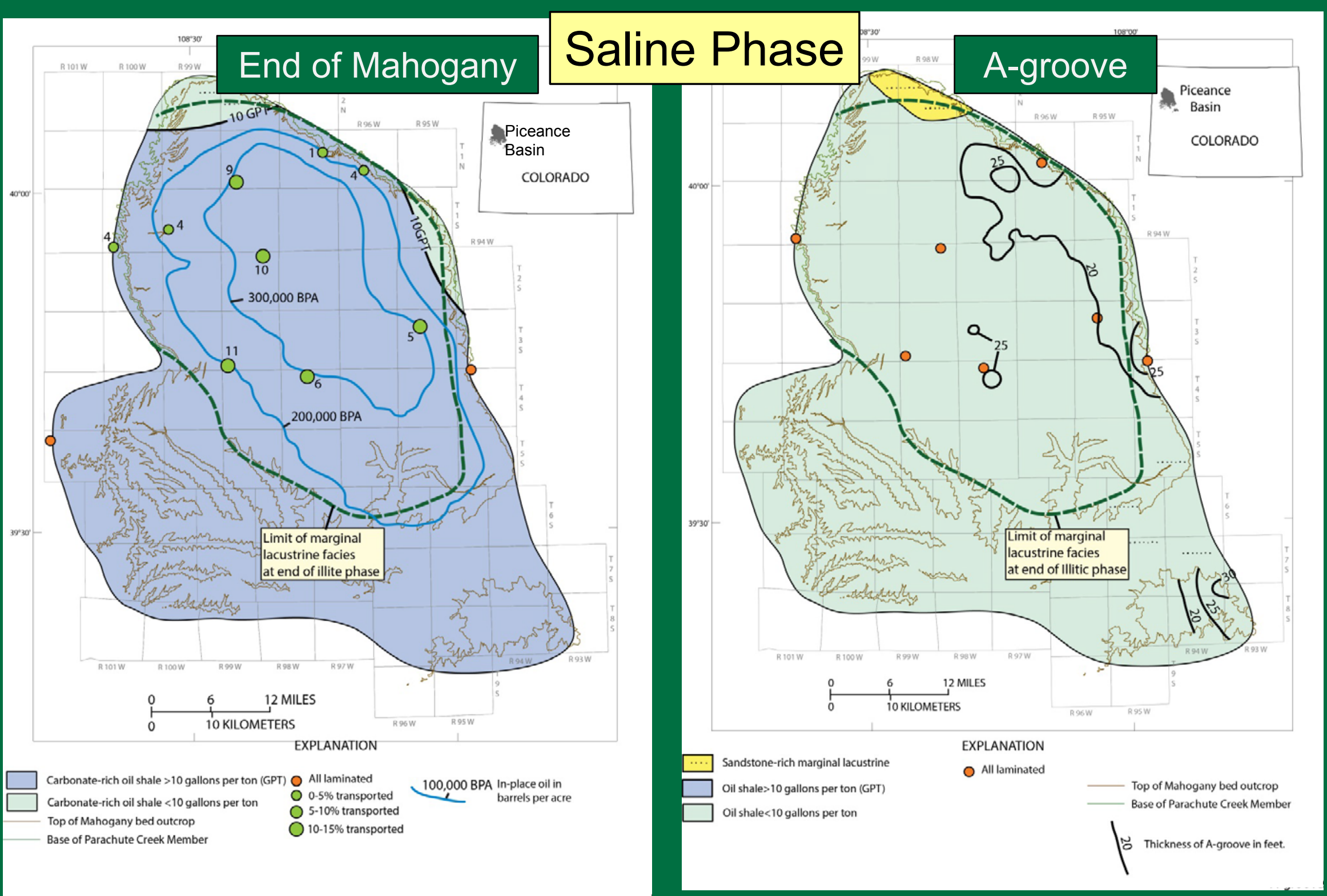

Deep-water conditions were dominant over the former marginal shelves during deposition of the Mahogany zone. Mass-movement deposits are rare in the Mahogany and absent in the overlying lean A-groove. 


\section{Infilling Phase}

Huge slumps and massmovement deposits of all sorts occurred during the infilling stage of Lake Uinta.
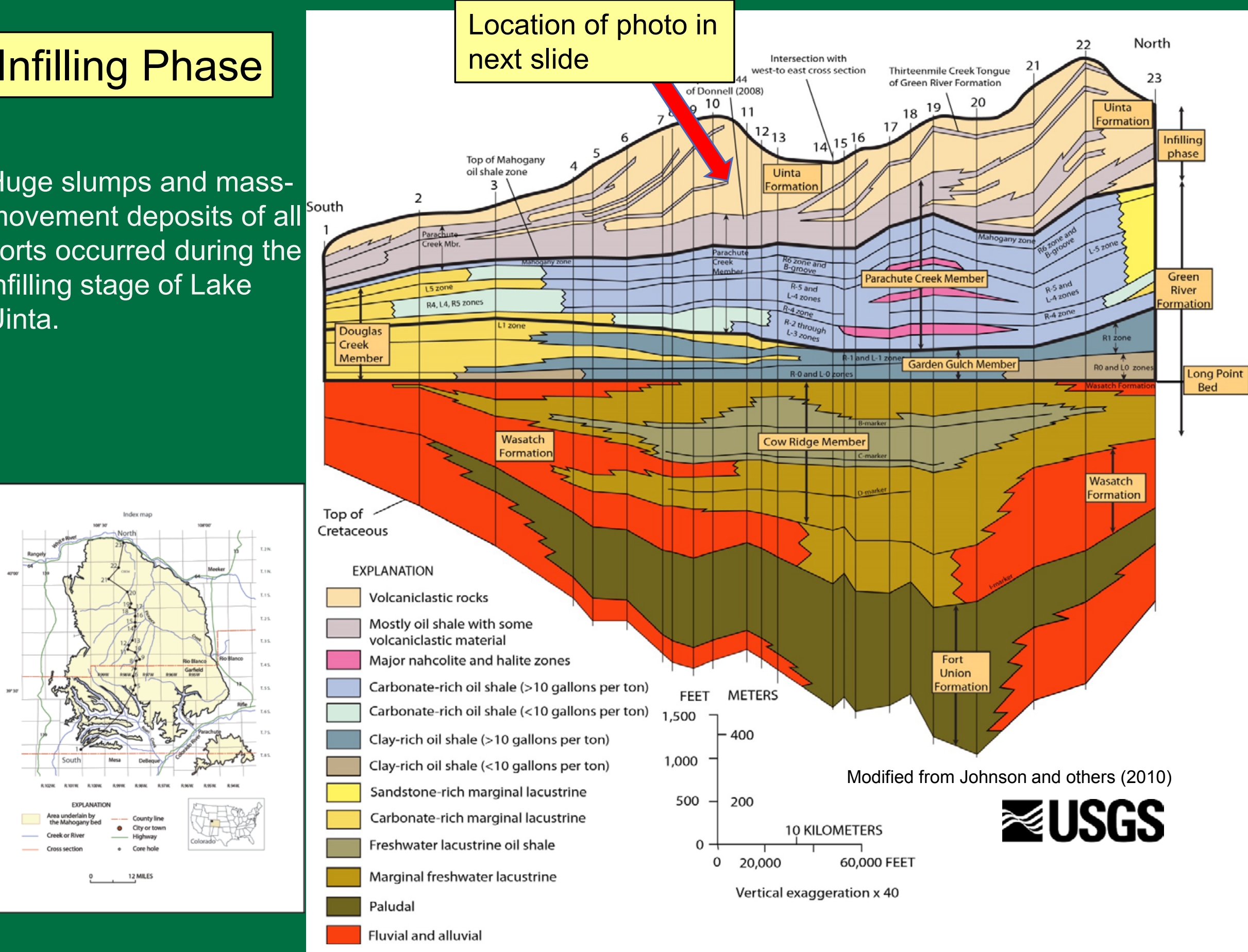


\section{Infilling Phase}

\section{ZUSGS}

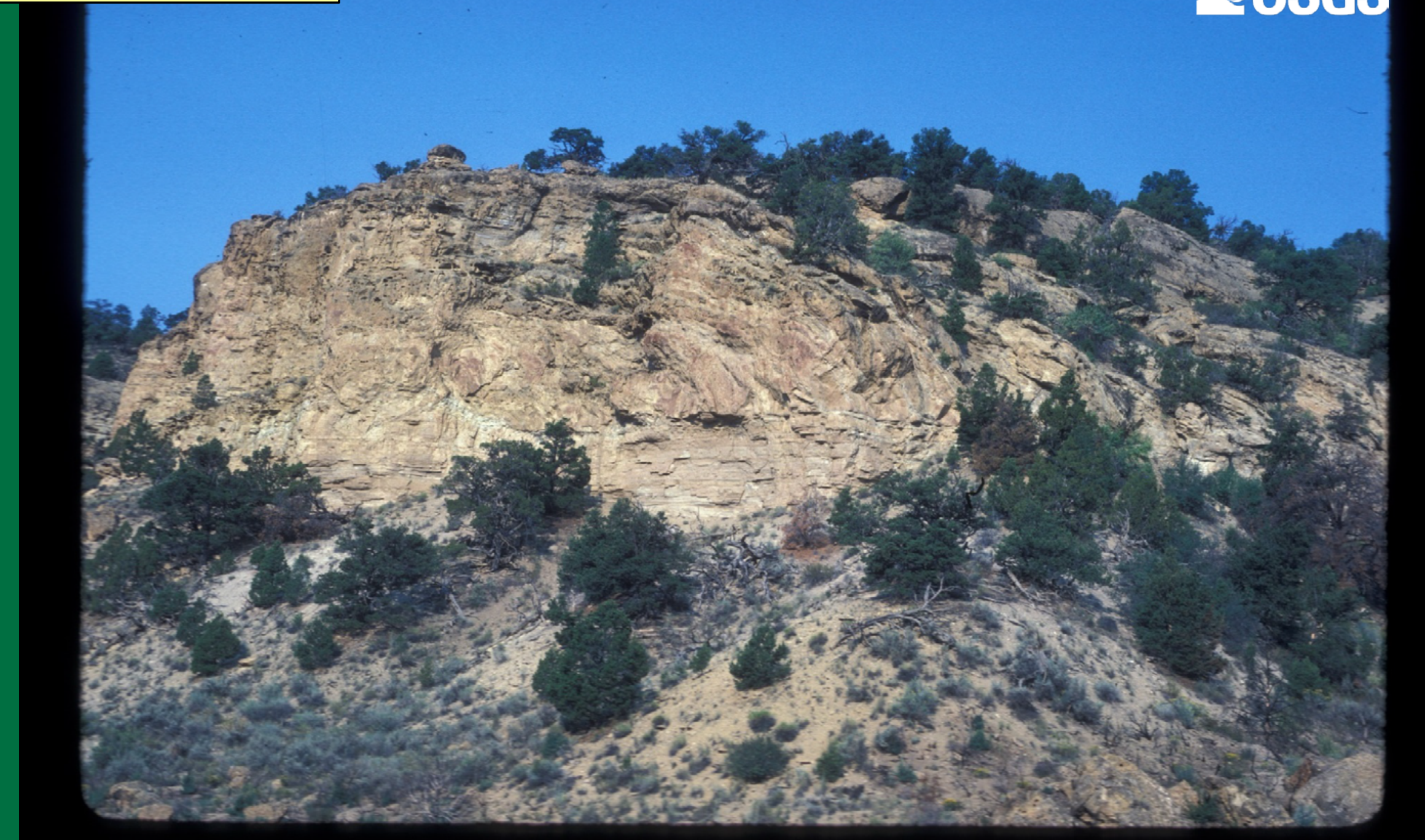

Following deposition of the Mahogany zone, Lake Uinta began to fill in from north to south. Slumps during the infilling stage of the lake can be several hundred feet thick, cover several square miles, and can be underlain and overlain by laminated marl and oil shale. This slump extends along a valley wall for 2.1 miles. 


\section{Conclusions}

- Mass-movement deposits during the illitic phase of Lake Uinta contain fewer clasts than the carbonate phase of the lake suggesting that the source area was mostly unlithified.

- Mass-movement deposits during the carbonate phase of the lake (Parachute Creek Member) contain abundant clasts indicating early lithification of sediments in marginal areas. These flows are most abundant in the central part of the depocenter.

- Mass-movement deposits accumulated at the base of the prograding shelves until the shelves reached the deep central part of the lake when progradation slowed. Massmovement deposits then reached the central deep part of the lake.

\section{‡USGS}




\section{Conclusions (continued)}

- Large amounts of organic matter were included in massmovement deposits.

- Highly saline brines that evolved on the marginal shelves may have been incorporated into the mass-movement deposits.

- Lean zones tend to include less mass-movement deposits than adjacent rich zones, possibly because organic-rich sediments were more prone to failure. 


\section{References Cited}

- Bradley, W.H., 1931, Origin and microfossils of the oil shale of the Green River Formation of Colorado and Utah: U.S. Geological Survey Professional Paper 168, 58 p.

- Dyni, J.R., 1981, Geology of the nahcolite deposits and associated oil shales of the Green River Formation in the Piceance Creek Basin, Colorado: Boulder, University of Colorado, Ph.D. dissertation, $144 \mathrm{p}$.

- Dyni, J.R., and Hawkins, J.E., 1981, Lacustrine turbidites in the Green River Formation, northwestern Colorado: Geology, v. 9, p. 235-238.

- Johnson, R.C., Mercier, T.J., Brownfield, M.E., Pantea, M.P., and Self, J.G., 2010, An assessment of in-place oil shale resources of the Green River Formation, Piceance Basin, Colorado-Oil shale and nahcolite resources of the Piceance Basin, Colorado: U.S. Geological Survey Digital Data Series DDS-69-Y, chap. 1, $187 \mathrm{p}$. 


\section{References Cited (cont.)}

- Johnson, R.C., and Brownfield, M.E., in press, Development, evolution and destruction of the saline mineral area of Eocene Lake Uinta, Piceance Basin, western Colorado: U.S. Geological Survey Scientific Investigations Report, 73 manuscript pages, 35 figures, and 2 plates.

- Mercier, T.J., and Johnson, R.C., 2012, Isopach and isoresource maps for oil shale deposits in the Eocene Green River Formation for the combined Uinta and Piceance Basins, Utah and Colorado: U.S. Geological Survey Scientific Investigations Report 2012-5076, 85 p., 1 pl.

- Tanavsuu-Milkeviciene, Kati, and Sarg, J.F., 2012, Evolution of an organic-rich lake basin-Stratigraphy, climate and tectonics-Piceance Creek basin, Eocene Green River Formation: Sedimentology, v. 59, no. 6, p. 1735-1768. 